\title{
The New Zealand Food Bill and Global Administrative Law: A Recipe for Democratic Engagement?
}

by

Bryce Adamson

A thesis submitted in conformity with the requirements for the degree of Master of Laws

Faculty of Law

University of Toronto

(C) Copyright by Bryce James Adamson 2012 


\title{
The New Zealand Food Bill and Global Administrative Law: A Recipe for Democratic Engagement?
}

\author{
Bryce Adamson \\ Master of Laws \\ Faculty of Law \\ University of Toronto
}

2012

\section{Abstract}

The New Zealand Food Bill is being passed amidst stern criticism of its content and the influence on it by multi-national corporations and the Codex Alimentarius Commission, whose food-safety standards motivated the bill. These concerns illustrate the large democratic and legitimisation deficits in global governance. One response to these criticisms and concerns is global administrative law, which focuses on promoting administrative law tools to enhance accountability. However, an examination of the Food Bill reinforces two main critiques of global administrative law: that it excludes addressing substance of international law and brackets democracy. I argue the limited GAL approach cannot be justified and the significant gaps in its approach require that it engage with democracy. I analyse the possibilities of global administrative law to engage with (to acknowledge and adopt) three theories of global democracy - deliberative, cosmopolitan, and radical pluralism. I argue deliberative democracy offers the most accessible option. 


\section{Acknowledgments}

Innumerable thanks to my supervisor, Professor Karen Knop, for all her guidance, ideas, critiques, and advice as well as to my parents for their everlasting support. 


\section{Table of Contents}

\section{Contents}

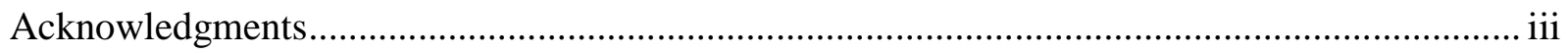

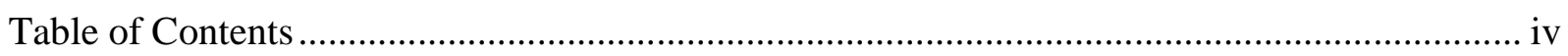

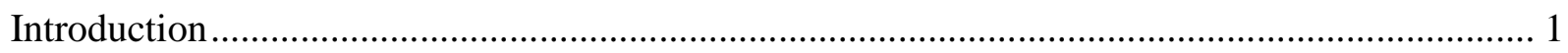

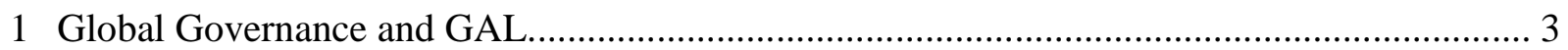

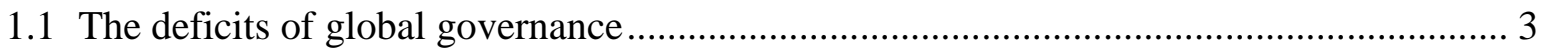

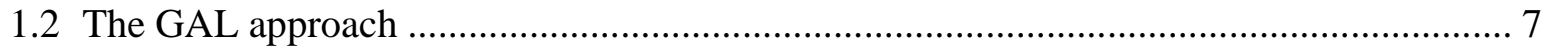

1.3 The GAL approach to the New Zealand Food Bill ................................................... 11

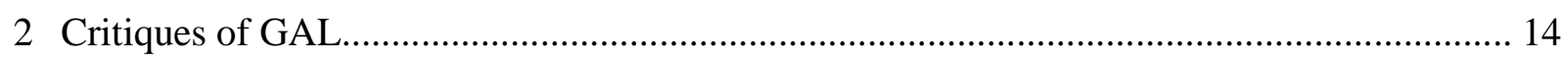

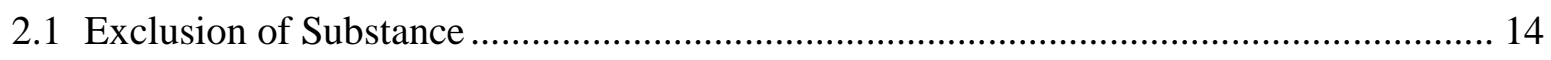

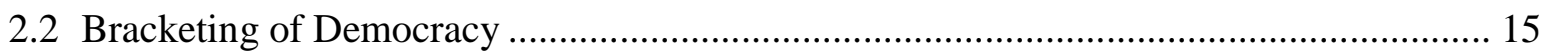

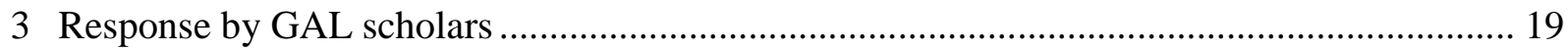

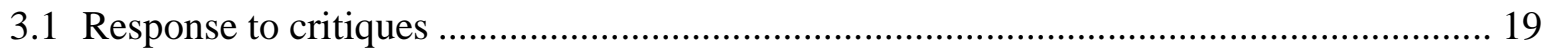

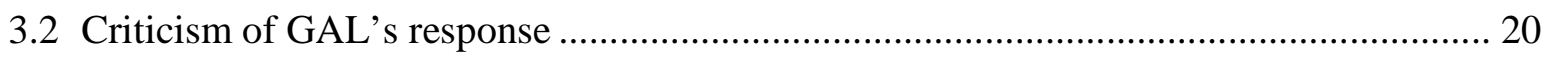

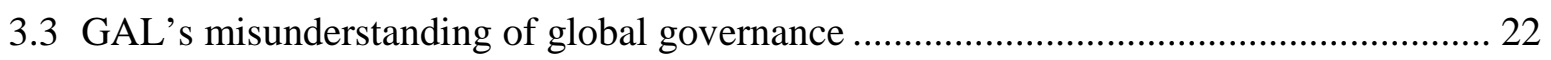

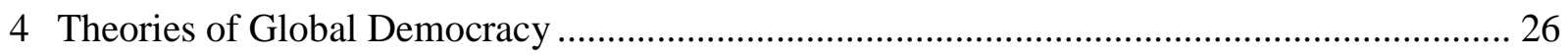

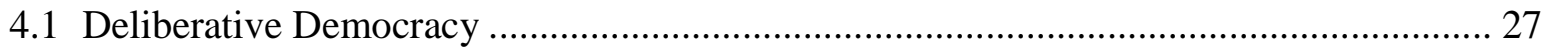

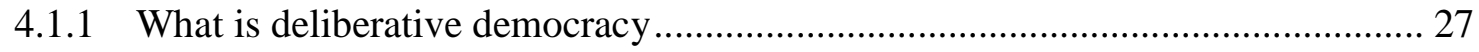

4.1.2 Wheatley's democracy beyond the state ....................................................... 30

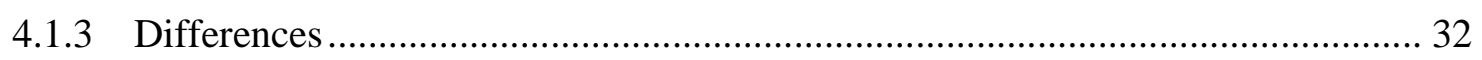

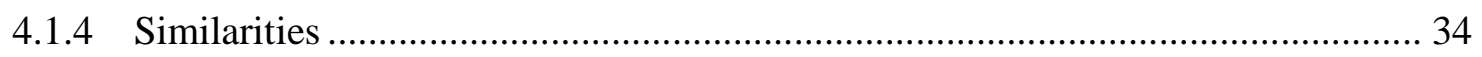

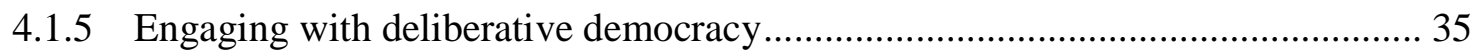

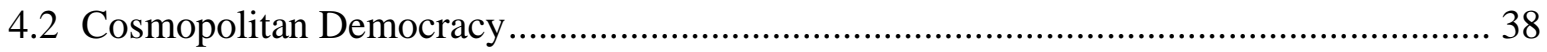




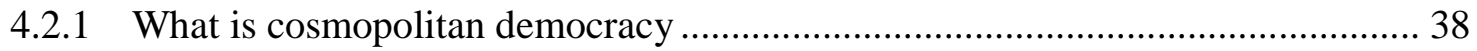

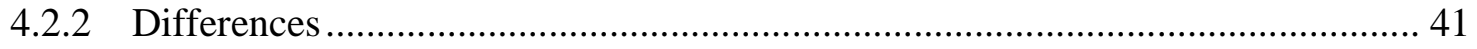

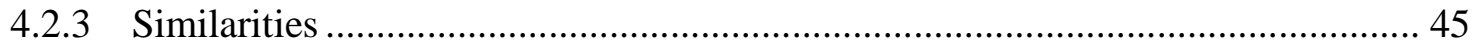

4.2.4 Engagement with cosmopolitan democracy …............................................. 46

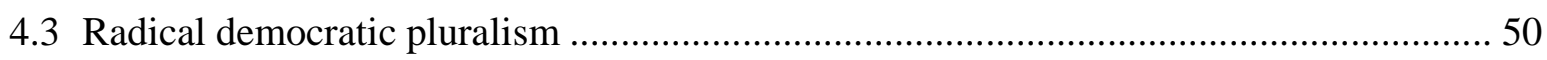

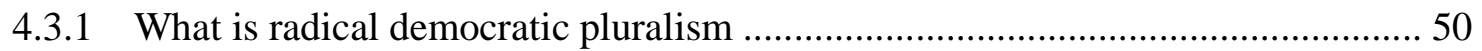

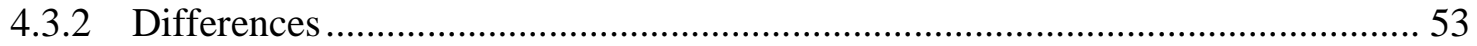

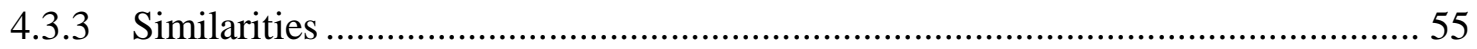

4.3.4 Engagement with radical democratic pluralism...............................................56

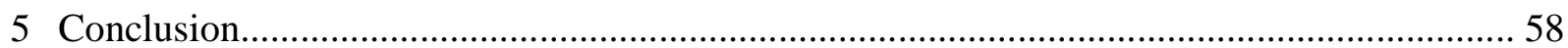




\section{Introduction}

For citizens of a peaceful democracy with pragmatic cultural and political traditions, New Zealanders have been generating unusual passion against what appears to be appears a relatively innocuous, even beneficial, policy measure: a simple food bill aimed at the "much needed modernisation of New Zealand's food safety legislation" that provides "an efficient, effective and risk-based regulatory regime that manages domestic food safety and suitability issues". Why these energetic, widespread, and vocal detractors?

The Food Bill appears to have touched a nerve in the New Zealand psyche by allegedly threatening deeply embedded values, such as self-sufficiency, pragmatism, and informal governance; Natural News, a non-profit website promoting "natural" alternatives, claimed "[t]he God-given human right to freely cultivate food is under attack in New Zealand [through] a "food security" bill...that will strip individuals of their right to grow food, save seeds, and even share the fruits of their labor with friends and family members". 2

Other activists claimed it threatened self-sufficiency and an online petition gained around 42,000 "signatures" ${ }^{3}$ - not an insubstantial amount for a country of four million. Of particular concern was the regulatory burden and increased difficulty the Food Bill posed for small scale activities and food producers and operators such as farmers markets, sausage sizzles, and home baking stalls. Nor was criticism limited to "natural" food consumer activists or individuals; Horticulture New Zealand, a commercial fruit and vegetable producers lobby group, called the bill 'ridiculous' ${ }^{4}$ and politicians, albeit more cautiously, criticised it.

Distinct from the implications of the particular content of the Food Bill for New Zealand culture, this thesis uses the case of the Food Bill to examine the larger implications of global governance

\footnotetext{
${ }^{1}$ Bill 160-1, Food Bill (NZ), 2010 session, explanatory note.

${ }^{2}$ Ethan A. Huff, NZ food bill to make growing food a government privilege rather than a human right (7 December 2011), online: NaturalNews

<http://www.naturalnews.com/034337_New_Zealand_food_freedom_human_rights.html>.

3 "Oppose the New Zealand Government Food Bill 160-2", online: PetitionOnline

<http://www.petitiononline.co.nz/petition/oppose-the-new-zealand-government-food-bill-160-2/1301>.

4،"Proposed NZ Food Bill 'ridiculous', says industry leader" (10 August 2011), online: Fresh Fruit Portal <http://www.freshfruitportal.com/2011/08/10/proposed-nz-food-bill-ridiculous-says-industry-leader/>.
} 
for democracy. The Food Bill implements a global regulatory regime - the Codex Alimentarius Commission ("Codex Commission") - and this fact triggered a variety of attacks and concerns. It was clear, one activist voiced, that "agribusiness giants like Monsanto want full control of the food supply, which means putting an end to small-scale agriculture systems that operate "off the grid," so to speak." Other critics believed that the "modernisation" rationale of the legislation masked its real purpose in providing market monopolies to multinational corporations.

More relevant for this thesis was the criticism of the diminished role of the New Zealand parliament - the centrepiece of national democracy - in this global regime. Comments on this track showed deep unease: "[i]n New Zealand, the goals of Codex Commission are being implemented at a rate that can only make the technocrats of the US and EU envious" 6 as another commentator put it. While it is easy to dismiss these (often inaccurate) attacks on the Food Bill as overheated "anti-globalisation" rhetoric, this case, in fact, exposes fundamental concerns about global governance and the genuine availability of democratic sites (like domestic legislatures) in which to debate and ultimately control the choices of a polity.

In this thesis I seek to explore some of these concerns using the Codex Commission as a case study. In particular, I seek to explore and critique one theory, global administrative law ('GAL'), which attempts to address the accountability of global governance bodies, such as the Codex Commission, but brackets questions of democracy, and excludes substantive international law. My central thesis is that for GAL to effectively address the deficits in global governance, provide a powerful framework for understanding global governance, and meet the concerns of ordinary people it must engage with (global) democracy.

I argue that that the main justifications of GAL scholars for not addressing these political or democratic concerns - pragmatism - is weak and that GAL suffers from an erroneous view of global governance that leads us to question its privileging of a limited, administrative response. I explore three theories of global democracy - deliberative, cosmopolitan, and radical pluralist -

\footnotetext{
${ }^{5}$ Huff, supra note 2.

6 "New Zealand Becomes Codex Alimentarius Incarnate: Food As Commodity, Not Nourishment" (26 November 2011), online: Gaia Health <http://gaia-health.com/gaia-blog/2011-11-26/new-zealand-becomes-codex-alimentarius-incarnate-food-ascommodity-not-nourishment/>.
} 
and contend GAL has some opportunities to address and adopt elements of these theories. While I suggest deliberative democracy offers the easiest opportunity for GAL to engage, substantial reformulation of GAL would still be required.

To do this I split this thesis into five sections. Section 1 explores the deficiencies of global governance and summarises the key elements of GAL. Section 2 explores two critiques of GAL in that it excludes the appraisal of substantive law and brackets the democracy question. Section 3 examines the response of GAL scholars to these challenges and criticises their reasoning.

In section $4 \mathrm{I}$ bring three theories of global democracy to bear on GAL by comparing and contrasting GAL with each democratic theory, considering the consistency between GAL and each theory, and ultimately evaluating the potential for GAL to address and adopt each theory. In the final section I conclude by commenting on the future potential of GAL as a normative project.

\section{Global Governance and GAL}

\subsection{The deficits of global governance}

Before examining the response of GAL to the issues raised by the New Zealand Food Bill, it is useful to discuss the broader democratic and legitimacy problems in global governance so the particular issues that arose in New Zealand can be placed in proper context. There are two major concerns that have arisen in international law and political science scholarship regarding globalisation. These are the impact of global governance on the principle and practice of democracy and the legitimacy of global governance actors. As Steven Wheatley, an international law scholar, has posited, "the globalisation and fragmentation of governance results in a loss for democracy as the people no longer decide all of those aspects of social, economic, and political that may meaningfully be subject to political contestation". 7

The loss Wheatley alludes to arises where the fundamental liberal tenets of individual rights and self-government are strained, in the case of the New Zealand Food Bill where the governance of non-state actors' actions are taken by (relatively) unknown and distant decision-makers, with

\footnotetext{
${ }^{7}$ Steven Wheatley, The Democratic Legitimacy of International Law (Portland, Oregon: Hart Publishing, 2010) at 1 [Wheatley, "Democratic Legitimacy"].
} 
limited opportunity of participation in their processes, and no opportunity to review their decisions. Nearly all New Zealanders were unaware of the promulgation of the original standards by Codex Commission nor had any (direct) input into these standards and would have had little to no knowledge or understanding of Codex Commission itself. ${ }^{8}$ This points to a large democratic lacuna within global governance.

While democracy is a heavily contested term, I suggest fundamental idea is that the ultimate source of authority and sovereignty lies with the people and thus the only legitimate form of governance (coercion) is by and with their consent. Where the state performs governance, there are established methods of establishing and displaying this consent, usually by periodic, free elections for legislative members and a doctrine of government accountability to the legislature and to the people. In global governance, the geographic and electoral connection between those who govern and those who are governed are severed and a major ontological query remains over the identity of the 'people'. Thus, global governance is divorced from the traditional, statist idea of democracy. To understand the democratic deficits global governance a more systemic fashion, I examine Jose Alvarez's useful and nuanced typology. ${ }^{9}$

Alvarez posits three main complaints in international law and institutions: vertical, horizontal, and ideological. Under the vertical complaint, three arguments are adduced. The first is that international institutions lack a democratic component in the form of electoral representation or similar domestic institution. ${ }^{10}$ Here he points to the lack of a world parliament and the insufficient representativeness of the UN General Assembly (not being tied to population but to jurisdictions) and the lack of checks and balances in international organisations. However, it is important to note that the linking of jurisdiction to representation also occurs in the domestic context. The representation of numerous legislatures, particularly upper houses, is delineated by virtue of territorial jurisdiction and not population. For example, Rhode Island and Texas both have two senators in the United States Senate despite the population of former being $1 / 25^{\text {th }}$ of the latter.

\footnotetext{
${ }^{8}$ The counter-argument that the democratic sites offered by the New Zealand parliament is addressed below.

${ }^{9}$ There have been numerous other attempts to provide an organisation classification of democratic deficiencies in global governance. See for example Andrew Moravcsik, "Is there a 'Democratic Deficit' in World Politics? A Framework for Analyst" (2004) 39 Government and Opposition 336.

${ }^{10}$ Jose Alvarez, "Introducing the Themes" (2007) 38 VUWLR 159 at 160.
} 
The second vertical complaint argument is that the nature of global governance allows decisionmakers to adopt norms that do not have domestic support. ${ }^{11}$ Again this concern is not restricted to the international plane; domestic democratic politics has allowed many unpopular laws to pass. However, with the increasing dislocation between the people and those who govern in global governance this risk is considerably exacerbated in the global sphere. Alvarez makes the further argument that international law is made by the executive branch of government yet all branches of the states are obliged to abide by international law, which empowers the executive branch at the expense of legislative and judicial branches. Democratic concern here arise from the exclusion of non-state actors in international law making, the privileging of (executive) state interests in international law making, and the democratic consequences for including many undemocratic nature states in the creation of international law and institutions. As we will see, GAL pays particular attention to the uneven participation in international law-making.

The last vertical complaint argument is that substantive rules adopted by international bodies fail to respect common democratic rights such as due process and other human rights. Here Alvarez cites the UN due process problems associated with the UN Security Council regime for 'targeted sanctions' as a prime example of this problem. ${ }^{12}$

The horizontal complaint concerns relations between states as the principal actors in international law. Here Alvarez contends that international law-making is illegitimate to the extent it does not treat sovereign states as horizontally equal. ${ }^{13} \mathrm{He}$ is particularly concerned where particular states have superior expertise that tilts international-law making in their favour or where procedural rules privilege their position. ${ }^{14}$ The archetypical example is the UN Security Council where the five permanent members have a right of 'veto' (and are protected from term limits). Wheatley suggests that Alvarez's concern here is for a one vote one state system that equates the sovereignty and equality of states with the political equality of citizens. ${ }^{15}$ It is not immediately

\footnotetext{
${ }^{11}$ Wheatley, "Democratic Legitimacy", supra note 7 at 23.

${ }^{12}$ For an analysis of this particular problem from a GAL perspective, see Cathy Powell, "The Role and Limits of Global Administrative Law in the Security Council's Anti-Terrorism Programme" (2009) Acta Juridica 32.

${ }^{13}$ Alvarez, supra note 10 at 162.

${ }^{14}$ Ibid.

${ }^{15}$ Wheatley, "Democratic Legitimacy", supra note 7 at 29.
} 
obvious which option - equal voting or weighting voting - has a stronger claim to democratic principles. However, I need not resolve this point here.

The last complaint concerns the ideological bias immanent in international law and institutions. Alvarez contends that the Western-dominated influence of the IMF and World Bank as well as similar minded technocrats reflects and privileges the dominating ideology of the West. ${ }^{16} \mathrm{He}$ notes that such criticism may be hard to disentangle from the vertical and horizontal complaints. $^{17}$ I agree. The privileging of state interests (particularly powerful Western governments and multi-national corporations) that the vertical and horizontal complaints highlight has consequences on the types of values engendered by global governance. This is similar to the problem of managerialism that Koskenniemi has critiqued, where under such an approach international law has no independent normative weight, existing only as a tool for achieving certain goals. ${ }^{18}$

These three complaints summarise the main democratic deficits in global governance and international law; however they do not answer or explore the vexed question of legitimacy. Some argue that (electoral) democracy represents the best and only form of legitimacy for global governance, ${ }^{19}$ while others point to alternative non-electoral means for legitimisation. ${ }^{20}$ However, although democratic deficits and legitimacy deficits are not the same, they tend to arise in common. ${ }^{21}$ In response to these deficits, GAL marks a major response by international law scholars to these concerns; however, its delineation and structuring of the democratic and legitimacy concerns differs significantly from broader encompassing typologies such as Alvarez.

\footnotetext{
${ }^{16}$ Alvarez, supra note 10 at 163.

${ }^{17}$ Ibid.

${ }^{18}$ Martti Koskenniemi "Global Governance and Public International Law” (2004) 37 Kritische Justiz Vierteljahresschrift für Recht und Politik 241; Martti Koskenniemi “The Fate of Public International Law: Between Technique and Politics" (2007) 70 Mod L Rev 1; Martti Koskenniemi "The Politics of International Law - 20 Years Later" (2009) 20 EJIL 7.

${ }^{19}$ As we will see, cosmopolitan democrats are the leaders amongst this group.

${ }^{20}$ See Terry Macdonald \& Kate Macdonald, "Non-Electoral Accountability in Global Politics: Strengthening Democratic Control within the Global Garment Industry" (2006) 17 EJIL 89.

${ }^{21}$ I will address legitimacy in this thesis, albeit in an oblique way because my arguments primarily concerns democracy and not legitimacy.
} 
GAL, as we will see, primarily seeks to enhance the accountability of global administration and thereby provide (some) legitimacy of global governance. It does not renounce broader concerns as elucidated by Alvarez and others; however, it provides a restricted response that excludes addressing democratic and other concerns. I now examine this approach in more detail.

\subsection{The GAL approach}

The Codex Commission and its influence in the New Zealand Food Bill is an exemplar par excellence of global administration that GAL pursues its particular approach to. The Codex Commission was created in 1963 by two existing international organisations, the Food and Agricultural Organisation ("FAO") and the World Health Organisation ("WHO"). It operates primarily as a regulatory body in setting global food standards. The primary purpose of these standards is to "[protect] the health of the consumers and [ensure] fair practices in the food trade". $^{22}$ These standards are created via a complicated eight-stage process ${ }^{23}$ involving participation of a variety of state and non-state actors; however, their final promulgation requires the consent of a majority of (state only) members. Membership is open to all member nations of the FAO and WHO who notify the Director-General of either international organisation. While the standards are not obligatory on member states, they gain a 'quasi-mandatory' or de facto legal effect ${ }^{24}$ by being incorporated into the WTO system via the SPS Agreement.

These activities fit squarely the ambit of GAL as it is 'rulemaking, adjudication, and others decisions that are not treaty-making or dispute settlement'. Indeed, Kingsbury, Krisch, and Stewart were keenly aware of the Codex Commission as a regulatory regime both ripe for GAL attention. They discussed it in their seminal article and classified it within their global administration typology as "hybrid inter-governmental-private administration"25 and highlighted

\footnotetext{
${ }^{22}$ Statutes of the Codex Alimentarius Commission at article 1 (a).

${ }^{23}$ Its procedural manual runs to some 220 pages in its current edition, which is incidentally 42 pages longer than the current Standing Orders for the New Zealand House of Representatives.

${ }^{24}$ Ravi Afonso Pereira, "Why Would International Administrative Activity Be Any Less Legitimate? - A Study of the Codex Alimentarius Commission" (2008) 9 German Law Journal 1693 at 1705.

${ }^{25}$ Benedict Kingsbury, Nico Krisch \& Richard B. Stewart, "The Emergence of Global Administrative Law" (2005) 68 Law \& Contemp Probs 15 at 22.
} 
the inclusion by the Codex Commission of NGOs in its decision-making process to strengthening its participation and transparency as emerging elements of the law of GAL. ${ }^{26}$

However, to fully understand the GAL approach to the New Zealand Food Bill and the Codex Commission a brief background on GAL is warranted to explore its definition, typology, conceptualisation of global governance, and principles.

The seminal article of $\mathrm{GAL}^{27}$ is The Emergence of Global Administrative Law by Benedict Kingsbury, Nico Krisch, and Richard B Stewart. They defined GAL as:

the mechanisms, principles, practices, and supporting social understandings that promote or otherwise affect the accountability of global administrative bodies, in particular by ensuring they meet adequate standards of transparency, participation, reasoned decision, and legality, and by providing effective review of the rules and decisions they make. ${ }^{28}$

Kingsbury, Krisch, and Stewart start by noting that much of global governance can be understood and analysed as administrative action and would be familiar to domestic public lawyers. $^{29}$ This global administrative action is separated from the familiar domestic administration system by the space in which it operates and the actors who inhibits that space. Kingsbury, Krisch, and Stewart label this space the "global administrative space" and characterise it as a multi-layered and extra-ordinarily varied landscape ${ }^{30}$. They argue this global administrative space conceptually extends beyond the traditional dichotomy of the strictly domestic regulatory space (governed by domestic public and administrative law) and inter-state

\footnotetext{
${ }^{26}$ Ibid at 38 .

${ }^{27}$ And the article which provides the fullest exploration of its conceptual underpinnings.

${ }^{28}$ Kingsbury, Krisch \& Stewart, supra note 25 at 17.

${ }^{29}$ Ibid at 17.

${ }^{30}$ Ibid at 19
} 
relations (governed by international law), ${ }^{31}$ containing elements of both these spaces although remains a relatively autonomous space. ${ }^{32}$

With the global administrative space set up, GAL provides a five-fold classification of classifies the actors who inhibit it. These are:

- Formal international organisations;

- Transnational networks of cooperative regulatory officials;

- Distributed administration by national regulators;

- Hybrid inter government-private arrangements;

- Private institutions with regulatory functions.

Collectively, these five categories of actors form the governance or regulatory authority of the global administrative space.

However, this typology of global administrative bodies is not the sole taxonomy within GAL scholarship. In an early examination of (international) administrative law, Kinney suggested a classification with four types of public international organisations, three types of transgovernmental networks, and international courts and tribunals as one group. ${ }^{33}$ Mitchell and Farnik, two Australian scholars, elaborated two main categories - international organisations and trans-governmental networks - with a third miscellaneous category for various entities. ${ }^{34}$ Even within the original GAL troika of Kingsbury, Stewart, and Krisch, Stewart has separately proposed a threefold classification of regulatory regimes. ${ }^{35}$ I examine the consequences of these semantic differences when I critique the GAL conceptualisation of global governance in section 3.3.

${ }^{31}$ Ibid at 26.

${ }^{32}$ Ibid.

${ }^{33}$ Eleanor Kinney, "The Emerging Field of International Administrative Law: Its Content and Potential” (2002) 54 Admin L Rev 415.

${ }^{34}$ Andrew D Mitchell \& John Farnik, "Global Administrative Law: Can It Bring Global Governance to Account?" (2009) 37 Federal Law Review 237 at 239-241.

${ }^{35}$ Richard B Stewart, "U.S Administrative Law: A Model for Global Administrative Law" (2005) 68 Law \& Contemp Probs 63 at 65 [Stewart, "US Model”]. 
Thus far, I suggest the GAL approach is a useful framework for understanding and organising new forms of (global) governance and for highlighting certain features of governance. It helps us to locate the Codex Commission within the wider global regulatory regime, expose the exercise of power and authority (as well as its problems) of the Codex Commission in setting food-safety standards, and offers us to consider the nature of international law in a globalised order where the separation between the global (Codex Commission) and the national (the New Zealand political and administrative systems) are blurred. However, GAL has two further important and symbiotic features - the identification of existing mechanisms and practices of accountability in global administrative agencies (the "law" of GAL) and proposals for reform to enhance accountability.

GAL scholarship maintains a fairly relaxed attitude to the distinction between lex lata and lex ferenda, offering a vision of reform that melds existing practices and new forms of accountability in its analysis. In particular, Kingsbury, Krisch, and Stewart's definition of GAL does not make an explicit distinction between these two forms of law. Thus, we see the exact nature and content of the "mechanisms, principles, practices, and supporting social understandings" is contested; however, there is agreement on several core principles from which GAL scholars deduce particular arrangements for reform.

In their original article, Kingsbury, Krisch, and Stewart focused on five primary mechanisms and principles: transparency, participation, reasoned decision, legality, and review. These derive largely from domestic (Western) administrative law systems. ${ }^{36}$ They did not propose the wholescale importing of these concept, identifying several constraints on transposition. ${ }^{37}$ Kingsbury has further cautioned that "[o]nly limited direct analogies may be drawn in the global administrative space from concepts of administrative law that apply within the state". 38 Thus, GAL scholars use domestic administrative law as a reservoir for mechanisms and principles to promote accountability and legitimacy but admit theoretical and practical problems in applying them verbatim to the global administrative space.

\footnotetext{
${ }^{36}$ They note the Western bias here is a potential critique.

${ }^{37}$ Kingsbury, Krisch \& Stewart, supra note 25 at 53.

${ }^{38}$ Benedict Kingsbury, "The Concept of 'Law' in Global Administrative Law" (2009) 20 EJIL 23 at 27.
} 
Harlow, another GAL scholar whose primary interest is in English and European administrative law, has evaluated six sources of principles of GAL but voices concern about the imposition of Western values through GAL. The by-product of this process, she cautions, is the privileging of Western interests and the juridification of political process. In the face of these problems, Harlow sees the preferable option is for GAL to engender a diversity and pluralism of its values. ${ }^{39}$ Krisch has similarly argued for a 'pluralist global administrative law', albeit in relation to who the constituencies of accountability in GAL rather than its values. ${ }^{40}$ Given the emphasis on pluralism in GAL, one may question what is "global" about its "law". However, Cassese still argues that there exists a global law in GAL. ${ }^{41}$

\subsection{The GAL approach to the New Zealand Food Bill}

With this this deeper understanding of GAL's main tenets, I examine its response to the Codex Commission and the New Zealand Food Bill in more detail. GAL scholars have more generally revealed several deficits in the standard-setting activities of the Codex Commission that are relevant to concerns over the New Zealand Food Bill. Given that GAL represents an pointedly administrative (law) response to deficits in global governance, its scholars have focused on criticism emanating from Rule of Law concerns such as the need to provide reasoned and open decisions, participation for affected actors to submit their views and concerns, and access to judicial review.

Livermore, who has written in depth on a (general) GAL application to the Codex Commission standard-setting activities, considers that inequality amongst participants is the largest failure of the Codex Commission's decision-making. ${ }^{42}$ He notes that:

[i]t would be grossly unfair and inaccurate to state that the efforts of the Codex to facilitate broad participation and deliberation over

\footnotetext{
${ }^{39}$ Carol Harlow, "Global Administrative Law: The Quest for Principles and Values" (2006) 17 EJIL 187 at 213-214.

${ }^{40}$ Nico Krisch, "The Pluralism of Global Administrative Law" (2006) 17 EJIL 247 [Krisch, "Pluralism”].

${ }^{41}$ Sabino Cassese, "Is There A Global Administrative Law?" in A. von Bogdandy, R. Wolfrum, J. von Bernstorff, P. Dann \& M. Goldmann, eds, The Exercise of Public Authority by International Institutions: Advancing International Law (Hiedelberg: Springer, 2010) 761 at 772.

${ }^{42}$ Michael A. Livermore, "Authority and Legitimacy in Global Governance: Deliberation, Institutional Differentiation, and the Codex Commission Alimentarius" 81 NYUL Rev 766 at 783.
} 
standards have been a failure. However, it is important to note that the SPS/TBT Agreements have placed very serious pressure on Codex processes and exacerbated existing deficiencies in Codex decision-making. ${ }^{43}$

Taking a GAL approach, Livermore suggests that an important and realistic response to these concerns is the judicial review of the Codex Commission decision-making by WTO tribunals to enhance participation. Bevilacqua and Duncan, two young GAL scholars interested in food governance, have written on the lack of transparency, explanations, and judicial review over the Codex Commission's standard-setting activities. ${ }^{44}$ Bevilacqua contends that the Codex Commission reveals that:

[t]he legal distance between the governed and the governors and the absence of mechanisms of control and sanctions on behalf of the public favour a lack of accountability of the decision makers and a decrement of citizens' participation and sovereignty. ${ }^{45}$

In response he urges greater transparency at the Codex Commission, which would help public understanding of policy results, establish a direct link between decision-makers and takers, and increase horizontal accountability. ${ }^{46}$

Some of these concerns were certainly borne out in the New Zealand Food Bill - the influence of major multi-national corporations, such as Monsanto, on the decision-making processes was a salient critique. Some detractors were also concerned about the lack of information and transparency regarding the activities of the Codex Commission, pointing out how little known its function was. However, as I argue, a GAL approach has major gaps in its theoretical and normative analysis, giving little or no consideration and analysis to certain features of the Codex Commission's standard-setting activities such as the likelihood that most New Zealander actors

\footnotetext{
${ }^{43}$ Ibid at 789.

${ }^{44}$ Dario Bevilacqua \& Jessica Duncan, "Towards a New Cosmopolitanism: Global Reflexive Interactive Democracy as a New Mechanism for Civil Society Participation in Agri-food Governance” (2010) 10 Global Jurist 1 at 8.

${ }^{45}$ Dario Bevilacqua, "The Codex Alimentarius Commission: increasing accountability through transparency" (Viterbo Global Administrative Law Series delivered at Viterbo, Italy, June 9-10 2006) at 12.

${ }^{46}$ Ibid at 17.
} 
affected by its standards have likely never heard of the Codex Commission, the impact of burdens on small-producers, whether it achieves the appropriate balance between health protection and trade practices, the power given to government agents, and the distribution of benefits and costs.

In short, many New Zealanders were highly censuring of the content of the food standards, implicitly concerned over the perceived inability for affected New Zealand actors to pursue their own policy choices, and anxious over the technocratic nature and impact of the Codex Commission. ${ }^{47}$ These concerns reveal a general unease amongst New Zealanders over who control of food policy and a wariness of distant actors controlling the private activities of individuals. As such, I suggest these criticisms go to the quality, nature, and values of democracy in the norm-making process of the Codex Commission and the New Zealand Food Bill.

GAL, as I argue from this brief illustration, thus misses many of the concerns of New Zealanders; however, this is intentional. GAL remains a pointedly limited project, concerned with the quality of the decision-making process, not the content of the decision or the wider context of the impact of these decisions. Thus, GAL provides a useful frame of analysis, but it misses several major issues in global governance and has a deliberately limited role for reform; the concerns of New Zealanders only partially overlap the mode of analysis and reform pursued by GAL scholars in relation to the Codex Commission.

GAL scholars have defended this limited approach on a pragmatic basis and thus consider it justified in order to ensure a cogent and feasible theory. But before I examine whether such a self-limiting approach is defensible, I explore two main critiques of GAL elucidated by academics that reflect and articulate in greater detail and clarity many of the concerns of New Zealanders and that gaps that are missing in its approach. These critiques also allow us to frame and examine the concerns of New Zealanders regarding the New Zealand Food Bill in a coherent fashion and to locate them within the broader debate over global governance. 


\section{Critiques of GAL}

\subsection{Exclusion of Substance}

The first major critique, echoing the disquiet of many New Zealand detractors regarding the content of the Food Bill, is that GAL improperly excludes the substantive content of international law from its purview and thus establishes an untenable distinction between substantive and administrative law. Chimni, a well-known third-world approach to international law theorist, attacks the theoretical construction and evolution of GAL that raises this distinction. His central thesis is that distinction between substantive and administrative law means that GAL is a limited tool of resistance and change, is likely to be co-opted by powerful states, and will have a weak role in injecting democracy and legitimacy into international law and its institutions. $^{48}$

Starting from the idea that global governance has transformed into a "global state" that regulates a wide range of activities he argues that the character of this state and its law must influence the character of GAL as a global law. As such, GAL shapes itself around how it interprets the development and nature of the global state and its institutions. In particular, he posits that GAL may adopt a narrow or broad definition depending on the political theory used to give meaning to these developments. ${ }^{49}$ The narrow definition - adopted by Kingsbury et al - rests on a dualistic understanding of international law in that it does not directly address individuals. The broad definition of GAL transcends this dualism through taking into account the distinctive features of the modern global state and ultimately rejects the bifurcation of international law into substantive and administrative law.

Therefore, where international law is characterised as an imperial endeavour, dominated by a privileged class, Chimni argues that the narrow, procedural approach of GAL cannot hope to generate real change or legitimacy because it excludes the review of the substantive content of those laws or norms. However, even if the power imbalances immanent in international law and

\footnotetext{
${ }^{48}$ B. S. Chimni, "Co-Option and Resistance: Two Faces of Global Administrative Law" (2005) 37 NYUJ Int'l L \& Pol 799 at 826 [Chimni, "Co-Option or Resistance"].

${ }^{49}$ B. S. Chimni, Global Administrative Law: Winners \& Losers (New York: Institute for International Law and Justice, 2005) at 9. [Chimni, "Winners \& Losers"].
} 
global governance are bracketed, Chimni maintains that the separation of substantive law and administrative law is unsustainable. ${ }^{50}$ This is because globalisation has fundamentally altered the nature of international law and its institutions such that states are transformed into administrative agencies of global governance, whose rule-making directly impacts individuals. In such an order, the state is incapable of mediating as a democratic forum to any creditable level.

Although Chimni's critiques emanated from a third world perspective, they have considerable relevance to the New Zealand Food Bill. Another major concern implicit in the debate was that the New Zealand House of Representatives was a shallow site for contestation over food-safety standards and did not fulfil its democratic role as an expression of national self-determination . Recall the anxiety over Monsanto and multi-national corporations' ability to manipulate foodsafety standards for their own benefits as well as over the eagerness of the New Zealand government to adopt the Codex Commission's standards.

Further, the supposed dualism of international law, in this case the Codex Commission's foodsafety standards, no longer represents an adequate response to democratic and legitimacy concerns as the power of the New Zealand state to pursue its own course and the ability of its primary democratic forum, the House of Representatives, was hamstrung by pressure to conform. We cannot allay concerns over the Codex Commission by arguing in a formal, positivistic way that the Codex Commission's standards do not directly affect New Zealanders. I suggest that Chimni's arguments reveal that input legitimacy - in the form of increased participation - cannot remedy concerns over the substance of norms at hand. Simply put, questions, such as I explored above in considering the gaps of a GAL approach, over the content over the standards matter to New Zealanders because they are affected by them and are not adequately dealt with by GAL.

\subsection{Bracketing of Democracy}

This second major critique of GAL is that it inappropriately 'brackets' the question of democracy. This critique again echoes many of the concerns of New Zealanders that in some

\footnotetext{
${ }^{50}$ Chimni, "Co-Option or Resistance", supra note 48 at 804.
} 
sense they were no longer determining their own policy choices. From GAL's inception, Kingsbury, Krisch, and Stewart recognised democratic deficits in global governance. They acknowledge that it not tenable to argue that "there are no real democracy or legitimacy deficits in global administrative governance because global regulatory bodies answer to states, and the governments of those states answer to their voters and courts ${ }^{51}$ - a version of the 'vertical' democratic complaint expounded by Alvarez. However, they explicitly exclude questions of democracy from the theoretical framework of GAL. Instead, they suggest "the better interim course might be to bracket questions of democracy" and "to focus on attaining more limited...objectives". 52

Susan Marks, a renowned international law democratic theorist, makes several pithy and poignant arguments against this democratic segregation. Fundamentally, she believes that "democracy belongs wherever public agendas are set and policies are framed",53 and develops several threads critiquing the conceptual and normative limitations of GAL.

Firstly, she highlights the danger of treating as technical that which needs to be treated as political. ${ }^{54}$ She defines the "political" catholically, meaning questions about "public priorities and social projects" and choices over allocation of goods and opportunities. The approach of GAL, she contends, aims to strengthen and clarify norms, with little understanding of how this structuring will benefit some and deprive others. ${ }^{55}$ The risk in the GAL approach is that examination and reform of decision-making processes can occur in a technocratic bubble, with minimal awareness of the political significance of those processes. This highlights the risks of a 'managerialist' theory of global governance where elites make decisions on a technical and rational basis with little participation from those affected by the decisions and understanding of the real-world consequences.

\footnotetext{
${ }^{51}$ Kingsbury, Krisch, \& Stewart, supra note 25 at 26.

${ }^{5}$ Ibid. at 50.

${ }^{53}$ Susan Marks, "Naming Global Administrative Law” (2005) 37 NYUL Int'1 L \& Pol 995 at 1000.

${ }^{54}$ Ibid at 996.

${ }^{55}$ Ibid at 997.
} 
Harlow, a GAL scholar, makes a similar warning. She argues that where GAL seeks to develop on universal principles it will leave no space for citizens to experiment and invoke change. ${ }^{56}$ Politics then becomes a series of juridified institutions where arguments are resolved on matters of procedure and definition. ${ }^{57}$ However, Harlow's concern appears to derive less from the democratic exclusion in GAL but rather against a universalist GAL. Her target is global constitutionalist; however, it is not necessarily true that juridification and universal are the same as constitutionalisation in the international sphere. ${ }^{58}$

Marks' other major concern regards the conceptual apparatus underpinning the exclusion of democracy from GAL's account and its embrace of accountability. This theoretical evolution involves a change from a participation model to a delegation model of accountability. She challenges the need to embrace a delegation model in which GAL ensures businesses' receive reasons for a decision and an opportunity for appeal, but little is done to connect ordinary people to the entities making decisions about their lives. ${ }^{59}$ I also suggest that underpinning GAL's solutions is an assumption that accountability mechanism based on the delegation model can substitute for (electoral) democracy, ${ }^{60}$ which I argue against below. Mark's final parlay against GAL concerns its understanding of democracy. She argues that in bracketing democracy, GAL appears to be eliding democracy with a fixed institutional structure.

Instead, democracy, she offers, is a multivalent tool; it can be used not only a descriptive label but as a critical concept for evaluating and reforming political arrangements by reference to certain principles, such as equality and inclusion. ${ }^{61}$ If we monopolise the descriptive function we face a question of what makes the institutional structure democratic, whereas Marks argues by elevating it as a critical concept we can evaluate democratic claim and democratise political

\footnotetext{
${ }^{56}$ Harlow, supra note 39 at 213.

${ }^{57}$ Ibid.

${ }^{58}$ Thomas Giegerich, "The Is and the Ought of International Constitutionalism: How Far Have We Come on Habermas's Road to a "Well-Considered Constitutionalization of International Law"?" (2009) 10 German Law Journal 31 at 42

${ }^{59}$ Ibid. at 99.

${ }^{60}$ Kanishka Jayasuriya, Riding the Accountability Wave? Politics of Global Administrative Law" (Perth, Western Australia: Asia Research Centre, 2007) at 14.

${ }^{61}$ Marks, supra note 53 at 1000.
} 
arrangements. $^{62}$ Finally, the ultimate value a multivalent understanding of democracy offers in GAL is its versatility. This means global democracy can be framed in ways not rigidly anchored to Westphalian politics, but brought to bear "wherever public agendas are set and policies are framed".

This last point reveals a tantalising opportunity. If we limit our understanding of democracy to a certain set of (Western) ideas anchored in the liberal state we may hamstring our ability to apply it to dynamic and fluid alterations of governance. Where we posit democracy on a broader basis - such as principles - we must and can use our normative and conceptual imaginations to engage global institutions with a concept that we claim to underlie our societies. More importantly, it opens space for GAL to engage with democracy.

As a response to democratic and legitimacy concerns in global governance, I argue that the weaknesses of GAL are exposed by both these criticisms. Take for example Livermore's detailed and careful work on the Codex Commission. His ultimate proposal, guided by GAL, is to allow judicial review of the Codex Commission's decision-making by the WTO Appellate body. This, I suggest, would provide little satisfaction to the people of New Zealand expressing their disquiet over the Codex Commission's food-setting standards. On a practical level it is unclear how an individual or a small group, even in a developed nation such as New Zealand, could gather the financial and technical resources required to appeal a decision in Switzerland. ${ }^{63}$ Those who could afford to do so are more likely to be wealthy individuals or multi-national corporations, echoing the argument of Chimni that GAL's promotion of judicial review as a mechanism is empty as it remains largely a theoretical possibility for many people. ${ }^{64}$

However, there are deeper problems with this response. Livermore is careful to exclude any kind of substantive review from his proposal as it is unlikely. ${ }^{65}$ Thus, the concerns of those directly affected in New Zealand over the impact of the food-safety standards and other substantive matters are ignored. Further, while such an appellate process may provide better

\footnotetext{
62 Ibid.

${ }^{63}$ Especially considering it is some $18,577 \mathrm{~km}$ from Auckland to Geneva.

${ }^{64}$ Chimni, "Winners \& Losers", supra note 49 at 17.

${ }^{65}$ Livermore, supra note 42 at 792.
} 
reasoned decisions, it does little, as Marks argues, to connect the Codex Commission to a smallfruit producer in a small town such as Nelson. It is difficult to avoid the conclusion that Livermore's GAL approach simply replaces one body beset with democratic deficits (the Codex Commission) with another one facing the same criticisms (WTO tribunals).

This point can be phrased in another way. Chesterman argues that the objective implementation of standards is not neutral unless those standards themselves are legitimate. ${ }^{66}$ Thus while an appellate body would strengthen the quality of implementation regarding international law norms, it does not provide adequate legitimisation for those standards themselves. GAL's Rule of Law preoccupation with the quality of the decision does not offer sufficient critical examination of the substance. On a broader theoretical level, the GAL response omits several issues alluded to above and more broadly risks, as Harlow and Marks warn, an ossification of politics. Participation, transparency, and review are all important concepts that would promote the legitimisation of the Codex Commission and thus help to alleviate democratic concerns in nations, such as New Zealand, where these standards are being implemented. However, we must be careful to remind ourselves that reliance on rules and processes cannot substitute for critically thinking about the ultimate goals of the international legal order. ${ }^{67}$

Having now explored the main criticisms of GAL and the power of these in articulating the concerns in the New Zealand Food Bill, I examine the response of GAL scholars to these critiques and argue that their justification for a self-limiting approach is not defensible.

\section{Response by GAL scholars}

\subsection{Response to critiques}

Krisch has taken the lead in responding to the critiques of GAL. The exclusion of democracy in the GAL approach is, he argues, justified along pragmatic lines. In essence, he contends that that GAL's narrow approach is justified because of the limited analytical and normative aims of

\footnotetext{
${ }^{66}$ Simon Chesterman, "Globalisation and public law: A global administrative law?" in Jeremy Farrall \& Kim Rubenstein, eds., Sanctions, Accountability and Governance in a Globalised World (New York: Cambridge University Press, 2009) 75 at 87.

${ }^{67}$ Emmanuelle Jouannet, "What is the Use of International Law? International Law as a 21st Century Guardian of Welfare" (2008) 28 Mich J Int'1 L 815.
} 
GAL. GAL brackets the democracy question because it does not aim to provide a full justification or legitimisation of global governance limits its role to exploring the normative values and presuppositions of institutional alternatives. ${ }^{68}$ Nor has GAL analysis, Krisch acknowledges, been situated in a broader theory of global democracy but had focused on a limited normative basis due to the difficulties of a full theorisation. ${ }^{69}$

In particular, Krisch strongly defends the limited ambition of GAL due to pragmatic reasons. He argues this by contradistinction, highlighting the alternative 'Postnational constitutionalism' that has a radical, utopian flavour impractical for short or mid-term change. ${ }^{70}$ While Krisch admits that political theory may always appear utopian at its inception, he believes this type of constitutionalism may represent too wide of a gap between theory and reality. The chasm between is and ought would, in his view, lead to lower demands, the legitimisation of deficient structures, and the construction of a global order along inegalitarian and dominating lines.

Nonetheless, Krisch acknowledges the problems of a limited ambition GAL, particularly the challenge in disentangling the administrative from broader normative ('constitutional') questions and the potential legitimisation of unjust global structures. However, in the final analysis, Krisch believes GAL is preferable to global constitutionalism as it "allows us to sharpen our focus and begin to answer crucial questions of global governance without leaping to grand designs borrowed from dissimilar contexts and likely at odds with the fluid and diverse character of the postnational polity". 71

\subsection{Criticism of GAL's response}

I find Krisch's justification unconvincing and I argue that his reasoning is weak by eliding democracy and global constitutionalism, purports to determine the final possibilities of reform based on unexposed and effete assumptions, and more deeply I argue that GAL suffers from a

\footnotetext{
${ }^{68}$ Nico Krisch, "Global Administrative Law and the Constitutional Law Ambition" in Petra Dobner \& Martin Loughlin, eds, The Twilight of Constitutionalism (New York: Oxford University Press, 2010) 245 at 254-255 [Krisch, "GAL Ambition"].

69 Ibid.

${ }^{70}$ Nico Krisch, Beyond Constitutionalism (Oxford: Oxford University Press, 2011) at 57 [Krisch, "Beyond Constitutionalism”].

${ }^{71}$ Krisch, "GAL Ambition", supra note 68 at 266.
} 
fundamental misunderstanding of global governance that negates a limited, administrative law response. In consequence, the careful framing of GAL may be initially attractive and cogent, it does not rest on sufficiently defensible grounds.

If we take a closer examination of Krisch's arguments, I contend it shows that he equates addressing democracy with global constitutionalism. This conceptual sleight of hand has significant detrimental consequences for the possibilities of global democracy in the world order. In particular, by equating democratic engagement with global constitutionalism, Krisch attaches the possible juridifying effects and ambitious nature of global constitutionalism to global democracy and thus cleverly renders democratic engagement by GAL impossible or unrealistic. Perhaps global constitutionalism is too unrealistic, but that does not necessarily lead us to conclude GAL can or should not engage with alternative conceptions of (global) democracy.

It is certainly not the case that global democracy is so evident and manageable that GAL could address it with ease. On the contrary, global democracy is vexed and complicated issue; however, GAL's exclusion of democracy gives cursory examination of what is meant by democracy and the opportunities for GAL and democracy. ${ }^{72}$ If democracy in global governance is imagined by GAL scholars as world government or a complex and ambitious project then pragmatism may be preferable. However, Krisch discusses one form of democracy - 'global constitutionalism' -- without imagining other forms of global democracy that allow for a midground to be found between pragmatism and utopianism. Krisch suggests the existence of a middle-approach, but ultimately rejects it.

I also argue that we must be critical where a scholar claims to have privileged knowledge over what is possible and therefore 'realistic' and 'pragmatic'. Pragmatism and realism are often instruments used to conceal underlying ideological or theoretical values and choices. Within international law writing, rationalism and realism can often operate in the background to protect

\footnotetext{
${ }^{72}$ Marks makes a similar point when, as I explored above, she criticises GAL for eliding democracy with certain, fixed institutional structures. I take the criticism further by suggesting that equating democracy with one particular and convenient theory (global constitutionalism) - and one that is foremost a (legal) constitutional theory - GAL scholarship is giving little thought to what democracy means.
} 
assumptions from scrutiny. ${ }^{73}$ Take the following argument of Krisch against the holistic ambition in that:

the attempt at refounding global governance on a grand scale in current political circumstances might easily play into the hands of those actors currently dominating international affairs: in a setting as inegalitarian as that of global politics, efforts at providing a stable framework of rules and institutions-at 'constituting' international society-are bound to sanction structures that primarily benefit the powerful. ${ }^{74}$

There are underlying assumptions at play in this kind of reasoning about the possibility, alternatives, and outcome of reform. The risk of 'constitutionalising' imbalance of power is certainly warranted; ${ }^{75}$ however, Krisch is making deep assumptions about the possibility of reform and more radical democratic visions as a reason for excluding their potential theoretical value. The potential for grander normative projects suggested by some global democracy and global constitutionalist scholars may depend as much on the attitudes to these institutions as much as realist concerns over power and interest.

Moreover, if Krisch is concerned with the inegalitarian global order, I suggest that small-scale reform that provides some greater participation for some NGOs or appeals rights to businesses will not bring about a greater reform to this inequality than larger projects such as global democracy. For example, Chimni has exposed the fallacy of judicial review as a remedy to inequalities as it is largely available, at least in third world countries, only to the elite classes.

\subsection{GAL's misunderstanding of global governance}

However, there is a much deeper problem with Krisch's defence of GAL's limited response that realism and careful elision of alternatives. I argue that the Codex Commission's standard-setting activities contain both legislative and administrative (executive) elements, which reveals a

\footnotetext{
73 Jutta Brunnée \& Stephen Toope, "Persuasion and Enforcement: Explaining Compliance with International Law" (2002) 13 Finnish Yearbook of International Law 1 at 8.

${ }^{74}$ Krisch, "GAL Ambition", supra note 68 at 255.

75 The innumerable problems in reforming the membership of the Security Council due to its 'freezing' of postWorld War II geo-politics is one major example of this risk that comes to mind.
} 
fundamental misapprehension in the GAL understanding of global governance as administration. This calls into question the entire GAL response to global governance deficiencies that are selflimited and privilege a narrow administrative law predicated on enhancing accountability.

As I have noted when discussing the background of GAL, Kingsbury, Krisch, and Stewart propose that "much of global governance can be understood and analyzed as administrative action". 76 This administration action is defined as "rulemaking, administrative adjudication between competing interests, and other forms of regulatory and administrative decision and management". 77 Given there is no shared definition of "administration" beyond the state, they posit a functional commonality with domestic administration, suggesting that "many of the international institutions and regimes that engage in "global governance" perform functions that most national public lawyers would regard as having a genuinely administrative character". 78 They admit, however, that administration at the global level contains legislative and adjudicatory elements, but maintain delineation between global administration and other modes of global governance.

When we consider the standard-setting activities of the Codex Commission and the impact on the New Zealand Food Bill I argue that such a distinction between administrative and other functions is hard to maintain or justify.

The Codex Commission operates a complicated seven step process for promulgating standards that would be very familiar to public lawyers advising on domestic legislative process. It involves the elaboration of a standard by a subsidiary body, the preparing of a draft and sending out to interested parties and receiving of comments, consideration of comments by the subsidiary body, the submission of the draft the actual decision-making body, further rounds of submission and comment, then final adoption by vote. I also note that standard-setting activities of the Codex Commission shares two common functions with domestic legislation - submission to a higher body for critical debate and that that body has power over the final adoption by the vote of (nominally) independent actors.

\footnotetext{
${ }^{76}$ Kingsbury, Krisch \& Stewart, supra note 25 at 17.

${ }^{77}$ Ibid.

${ }^{78}$ Ibid.
} 
Further, the New Zealand Food Bill illustrates the legislative functioning of the Codex Commission by the impact of standard-setting on states and the nature of those standards. New Zealand did not adopt the Codex Commission food standards as domestic administrative by instructing the Ministry of Primary Industries to create regulations for submission to the Executive Council. ${ }^{79}$ The food-safety standards promulgated by the Codex Commission required a legislative response by New Zealand. This was not an accident; the significance of the Codex Standards required primary and not secondary legislation. The General Policy Statement to the New Zealand Bill noted that it (my italics) "introduces substantial reforms to the regulatory regime for the safety and suitability of food" and replaces one statute and regulation and amends two further statutes.

Thus, where the standard-setting activities of the Codex Commission require a legislative response, it is difficult to label these functions as administrative. However, at the same time the Codex Commission also carries out administrative or executive activities such as the coordination of regional food standards. Bevilacqua has also recognised the dual functioning, stating that "[c]onsidering the influence of the standards on national Parliaments and administrations and the discretion of the decision-makers, the CAC entails a function, which is of legislative and executive nature at the same time". 80

Further, the broader nature of global governance is recognised even within GAL lineage. Esty has offered a broader array of governance to apply GAL, including includes treaty-making and dispute resolution between parties - two categories of governance activities that Kingsbury, Krisch, and Stewart exclude from administration. ${ }^{81}$

But if the Codex Commission activities are not best understood as a legislative function according to Kingsbury, Krisch, and Stewart, then what is? For them it is treaty-making, i.e. hard law. I suggest the true distinction between administrative and legislative and judicial

\footnotetext{
${ }^{79}$ This is the body in New Zealand, headed by the Governor-General, which officially promulgates most regulations; however, this is simply a matter of form. Most debate occurs internally within the relevant domestic agency, during and after stakeholder consultation, and at Cabinet meetings where the regulations are proposed by the responsible minister and agreed (or not) to by the Cabinet as a whole.

${ }^{80}$ Bevilacqua, supra note 45 at 1.

${ }^{81}$ Daniel C Esty, "Good Governance at the Supranational Scale: Globalizing Administrative Law" (2006) 115 Yale LJ 1490 at $1497-98$.
} 
activities in the global realm by Kingsbury, Krisch, and Stewart is based on form, not function, as it is determined by reference to the status of the norms created as either hard law (legislative) or soft law (administrative).

Where the substance and status of international norms are deeply contested and the functions of global governance are blurred, the misapprehension of GAL operates to render its response inappropriate and insufficient. It also strikes as odd that the nuance and depth of analysis given by Kingsbury, Krisch, and Stewart regarding the new forms of governance - and which emphasises its newness, multi-valence, and power - would result in it being labelled administration. It is not that GAL wrongly views global governance as involving administration - much of it is $-{ }^{82}$ but as the Codex Commission and the New Zealand Food Bill show global governance involves more than administration and resists functional bifurcation.

The result is that if global governance is not best (or even primarily) understood as administration, then an administrative (law) response can no longer be privileged and must be defended on other grounds. ${ }^{83}$ Thus GAL may take a self-limiting approach, but this is unable to provide a defensible normative and descriptive framework for remedying deficits in global governance where it only aims its conceptual and critical teeth at a slice of the governance activities - an approach that in particular lacks future potential to respond to an emerging global state of multifarious functions. In short, how a global space is created can have an important impact on the efficacy of different administrative law techniques and functions. ${ }^{84}$

I contend that it is theories of democracy that are far better placed to respond to deficits in global governance as they address all functions of governance, promote a variety of responses (not simply enhancing accountability), examine substance and power relations, and thus can provided a far more nuanced and powerful vision. Thus it is only by engaging with global democracy that GAL can be both defended as a descriptive approach and offer a fuller framework for

\footnotetext{
${ }^{82}$ See also Janet McLean, "Divergent Conceptions of the State: Implications for Global Administrative Law" 68 Law \& Contemp Probs 167. She notes that "the sites of global governance are not necessarily the sites of global administrative law" (ibid at 168).

${ }^{83}$ Even if the nature of global governance is currently best understood as administration, pursuing an administrative law-minded reform agenda is problematic where a range of state functions - legislative, judicial, and executive - are increasingly moving to the global or transnational level.

${ }^{84}$ McLean, supra note 82 at 168.
} 
understanding and critiquing the Codex Commission and responding to New Zealanders concerns over the Food Bill.

To recap, so far in this thesis I have briefly explored the democratic deficits in international law and global governance and discussed the response of GAL to these as particularly illustrated through the New Zealand Food Bill. I have explored two critiques of GAL's separation of substantive and administrative law that articulate concerns over the New Zealand Food Bill. I have also examined the response of GAL scholars to these criticisms by claiming a pragmatic path, but I have showed this reasoning is weak and based on a misapprehension of global governance as administration. The alternative and better path forward is for GAL to engage with democracy.

\section{Theories of Global Democracy}

If GAL represents an inadequate response to the concerns of New Zealanders over the Food Bill and the Codex Commission and further democratic theorising is required, how might this be done? In short, if GAL should not exclude democracy, how might it include it? In this section I engage GAL with three particular theories of global democracy - deliberative democracy, cosmopolitan democracy, and radical democratic pluralism in an attempt to answer that question.

I define the process of engaging with democracy as encompassing two steps - to address it generally and then to adopt a particular version. The first step is for GAL scholars to acknowledge the need, relevance, and use of democracy generally to its theory and not simply to exclude it (this is largely my argument in sections 2 and 3). The second step is to adopt a version of democracy as its normative superior and seek to integrate it by absorbing its key analysis, framework, and values or if already largely consistent to more explicitly espouse and reflect the particular democratic vision. This is admittedly an abstract definition because the exact nature and possibility for engagement is only clear when a particular theory of global democracy is analysed. My methodological approach is to consider GAL and each theory of global democracy individually by exploring their differences, similarities, consistency, and then discussing the opportunities and limits for GAL to engage with each theory by reference to the Codex Commission and the New Zealand Food Bill as a case-study. 
Underlying my analysis is the belief that by GAL engaging with theories of democracy a middle ground between the improper legitimising effects of a narrow GAL approach and the utopian hopes of global constitutionalism or a way beyond some of the intractable problems of both may be found. Such reformulated GAL would provide greater possibilities to provide New Zealanders (and others subject to global governance regimes) with the ability to connect more directly with the Codex Commission, powerful tools for challenging and addressing the deficits revealed by the New Zealand Food Bill, and a framework for future reform of global governance. My analysis suggests ${ }^{85}$ deliberative democracy and cosmopolitan democracy offer opportunities for GAL to engage with democracy; however, substantial theoretical reconstruction would be required.

\subsection{Deliberative Democracy}

I argue that my analysis of GAL and deliberative democracy by reference to the New Zealand Food Bill shows that the former reflects some tenets of deliberative democracy, such as an emphasis on participation in decision-making of affected non-state actors, which highlights some consistency between the two. However, a difference in underlying rationale for participation between the two may pose conceptual problems as GAL sources the need for participation in Rule of Law and natural justice while deliberative democracy locates it in consent and sovereignty. Consequently, while GAL has significant potential to adopt deliberative democracy, considerable modification may be needed.

\subsubsection{What is deliberative democracy}

The theory of deliberative democracy I elucidate here is primarily that of Jürgen Habermas and its adaption to the global realm by Steven Wheatley. Deliberate democracy is a political theory that focuses on issues of procedure in democratic politics. It shares elements of both the liberal and republican visions of democratic society. Deliberative democracy posits that political truths, the exercise of authority, and the legitimacy of law are discovered by and grounded in processes 
of discourse and deliberation. Accordingly, democracy and discourse are two sides of the same coin; ${ }^{86}$ they reinforce each other and form an ineluctable link.

Under deliberative democracy, the legitimacy of law is an exercise of authority. Law is the ultimate outcome of democracy and discourse so that its legitimacy is dependent on the discursive (democratic) process of its creation. Thus, for law to be legitimate, deliberative democracy requires a communication act that "as participants in rational discourses, consociates under law must be able to examine whether a contested norm meets with, or could meet with, the agreement of all those possibly affected". 87

Deliberative democracy opines that no one actor can claim a privileged position in debates and legitimate law results from reason communications aimed at establishing a consensus among participants. ${ }^{88}$ Therefore, the process of, and participation in, debate is essential to deliberative democracy. In the debate, participants establish their 'political truth' through reasoned arguments and in language that others understand and for reasons others might accept. ${ }^{89}$ If consensus is impossible amongst the participants then movement is made to achieve agreement and if this fails the discourse moves to bargaining. ${ }^{90}$

As such, consensus represents a fundamental idea in deliberative democracy. In theory, deliberative democracy requires the consent of all participants and not simply a majoritarian aggregate of preferences. As Habermas puts it, "just those...norms are valid to which all possibly affected persons could agree as participants in rational discourses". 91 He defines the participants are those who are "possibly affected", namely, "anyone whose interests are touched by the foreseeable consequences of a general practice regulated by the norms at issue". 92

\footnotetext{
${ }^{86}$ Denise Vitale, "Between deliberative and participatory democracy: A contribution on Habermas" (2006) 32 Philosophy \& Social Criticism 739 at 745.

${ }^{87}$ Jürgen Habermas, Between Facts and Norms: Contributions to a Discourse Theory of Law and Democracy (Cambridge, Massachusetts: MIT Press, 1996) at 104.

${ }^{88}$ Wheatley, "Democratic Legitimacy", supra note 7 at 103.

89 Ibid.

90 Ibid.

${ }^{91}$ Habermas, supra note 87 at 107.

${ }^{92}$ Ibid.
} 
Underpinning the requirement for the "concurring and united will of all" free and equal citizens to legitimise law ${ }^{93}$ is the idea of the state as a voluntary association of free and equal persons. ${ }^{94}$ The people the state are therefore self-determining, and they must understand themselves to by both the subjects and authors of the norms. ${ }^{95}$ The institutionalisation and constitutionalisation of the process of discourse and participation in is also fundamental. Democracy must guarantee the reasonable, communicative process of opinion- and will-formation through the institutionalisation of rights that grant equal participation in norm creation. However, for Habermas, a democracy also requires an extensive list of rights beyond participation, such as human rights.

Given the impossibility for all people to engage in direct and simple interactions on all issues, Habermas looks to the parliamentary principle as a solution. This requires the establishment of representative bodies for deliberation and decision making. ${ }^{96}$ A person is 'represented' under this model, where their representatives ensure decision-makers take into account the opinions, views, and interests of those affected by the law-making. ${ }^{97}$ Habermas also proposes a public sphere as a social site between society and the state where informal streams of communication emerge that parliament must remain open to ${ }^{98}$ in order to 'representative'.

In sum, deliberative democracy under Habermas focuses on a need for a discursive process of debate when creating norms and making decision with equal participation of all those affected and an overall aim of achieving consensus for the public good. Habermas believes democratic law-making (deliberative democracy) is only possible within the state because there is no capacity for the global public to imagine itself as a voluntary association of free and equal cities as well as for collective will-formation. ${ }^{99}$ Wheatley, however, has provided a model for deliberative democracy that goes beyond the state that I utilise in my analysis.

\footnotetext{
${ }^{93}$ Ibid at 32.

${ }^{94}$ Wheatley, "Democratic Legitimacy”, supra note 7 at 104.

${ }^{95}$ Ibid.

${ }^{96}$ Habermas, supra note 87 at 170.

${ }^{97}$ Wheatley, "Democratic Legitimacy", supra note 7 at 112.

${ }^{98}$ Habermas, supra note 87 at 171.

${ }^{99}$ Wheatley, "Democratic Legitimacy", supra note 7 at 312.
} 


\subsubsection{Wheatley's democracy beyond the state}

Wheatley's thesis is that the legitimate exercise of authority in global governance by non-state actors and the establishment of democratic laws in global governance require the "institutionalisation of the (deliberative) principles of equality and public reason."100 While he acknowledges that many non-state actors claim to global regulatory power framed in terms of law, he argues that this exercise of power cannot be legitimate without the adoptions of these norms in accordance with deliberative democracy. ${ }^{101}$

Wheatley seeks to overcome the problem of applying deliberative principles in the disaggregated and multi-level regimes of global governance by modifying Habermas's model in two connected ways: by re-characterising the political community and by realigning the scope of participation required.

Regarding the first adaptation, Wheatley posits that a "[d]emocracy does not define its own boundaries"; a political community is defined rather by the assertion of authority. ${ }^{102}$ Whereas the state under deliberative democracy the political community is relatively uncontroversial and defined by the state law system, there are no such axiomatic demos for global governance. ${ }^{103}$ Instead, Wheatley argues, in the global order the political community is defined by the exercise of authority. ${ }^{104}$ This interpretation allows the conceptualisation of a relevant political community while avoiding the intractable issue of establishing or delineating a global free and equal community of citizens under international law required by Habermas.

The second conceptual evolution regards participation rights. Wheatley argues that the existing criterion of "all affected" is unsuitable for deliberative democracy beyond the state as it invariably privileges a human-rights and a materialistic Weltanschauun, produces constantly fluctuating boundaries of political constituencies on policy issues, and tends to become more

\footnotetext{
${ }^{100}$ Ibid. at 311.

${ }^{101}$ Ibid. at 315 .

102 Ibid.

${ }^{103}$ Steven Wheatley, "A Democratic Rule of International Law" (2011) 22 EJIL 525 at 541 [Wheatley, "Democratic Law"]

${ }^{104}$ Ibid at 312 .
} 
indeterminate and subjective. ${ }^{105}$ A better criterion he suggests is "all subjected" to a particular regime, which includes state and non-state actors' subject de jure and de facto to the global regime authority. ${ }^{106}$ With this shift, those subject to global governance can thereby regard themselves as the authors of the same normative order, thus fulfilling a key requirement of deliberative democracy.

With these two adaptations in place, Wheatley re-states the process of deliberative democracy under global governance. In particular, he argues that non-state actors must give public reasons for decisions, recognise and give effect rights to political participation, and establish mechanisms for participation of those subjected to proposed regulations. ${ }^{107}$

The principle of representation requires those subject to a global regime have their interests and perspectives included in the deliberation. Thus, for an international law to be legitimate it requires the assent of representatives with consensus achieved through rational discourse. ${ }^{108}$ Wheatley further states that where the norm or law in question has significant importance it should be adopted by representative institutions and not committees of experts, which may necessitate the established of assemblies along the lines of the European Parliament. ${ }^{109}$

However, Wheatley does not promote the 'paraliamentarisation' of all international institutions; he emphasises that no single mode of applying the representation principle is applicable to all international organisations. ${ }^{110}$ It is important, Wheatley affirms, that these sites of deliberation are sensitive to the public opinion generated in the global public sphere and mechanisms (such as the involvement of international civil society) are opened to allow for the transmission of public opinion.

In sum, Wheatley's formulation of deliberative democracy for global governance requires the following:

\footnotetext{
${ }^{105}$ Wheatley, "Democratic Legitimacy", supra note 7 at 325.

${ }^{106}$ Ibid at 326.

${ }^{107}$ Ibid at 317.

108 Ibid.

109 Ibid.

${ }^{110}$ Wheatley, "Democratic Law", supra note 103 at 543.
} 
- There must be regulatory directives framed in terms of international law;

- The global 'regulatory' actor must exercise legitimate authority;

- Legitimate authority requires the adoption of regulations in accordance with right reasons;

- The right reasons are determined through deliberative democratic processes that include the interests and perspectives of those subject to the regime. ${ }^{111}$

\subsubsection{Differences}

I suggest there are two important points of departure between GAL and deliberative democracy as elucidated by Steven Wheatley (which I will refer to as "global deliberative democracy" from now on to distinguish it from the Habermas's state conception), namely, in their aims and rationale for participation.

The aim of global deliberative democracy is, like cosmopolitan democracy, manifestly higher and more expansive than that of GAL. Global deliberative democracy enunciates the sole mode legitimisation of global governance and international law norms via the principles of deliberative democracy. ${ }^{112}$ Wheatley confirms that "[i]n the absence of the (legitimate) authority provided by (deliberative) mechanisms...global regulators cannot claim the right to determine the normative position of legal persons". 113 Thus, the aim of global deliberative democracy is to provide the full and sole means of legitimisation. GAL, I argued previously, is less ambitious and authoritative; it does not seek to rearticulate and justify global governance on a democratic basis, but to develop specific mechanisms for enhancing the accountability of specific global administration regimes.

This reveals a significant inconsistency between global deliberative democracy and GAL. Under the former, the choice is stark - either the democratic project is set aside or global governance is made more democratic. ${ }^{114}$ Where the democratic project is set aside this necessarily implies that

\footnotetext{
${ }^{111}$ Wheatley, “Democratic Legitimacy”, supra note 7 at 332.

112 Ibid at 2.

${ }^{113}$ Ibid at 318 .

${ }^{114}$ Wheatley, "Democratic Law", supra note 103 at 526.
} 
there is no (or illegitimate) authority in global governance. ${ }^{115}$ Thus, where the (deliberative) democratic project excluded, there is a dearth of theoretical space for alternative but lesser forms of legitimacy (such as enhancing accountability) to garner normative justification for governance. One implication of this inconsistency is that where GAL scholarship refuses to adopt deeper rights of non-state actor participation its deliberative (democratic) quality may be insufficient to produce legitimate authority.

The second difference I highlight is the rationale underlying the promotion of participation by GAL and deliberative democracy. Deliberative democracy is a liberal democratic project; amongst its underlying principles are the equality of citizens and the need for consent as a reflection of the collection self-determination of people. Under global deliberative democracy, sovereignty or 'constituent power' requires citizens to jointly be the authors of their constitutional identity, thus those who are subject to a constitutional order must 'co-institute' it and have full participation in its creation. ${ }^{116}$

In relation to global governance, Wheatley requires the participation of all those subjected to the regime (although this may indirectly achieved through representatives). I suggest underlying the global deliberative democracy notion of participation is the idea that the consent of the global demos, as a type of sovereign, provides the justification and need for participation.

Whereas I argue that under GAL a more pragmatic relationship exists between those who are governed and those who govern. Participation is promoted as an administrative law principle and it is based on ideas of natural justice and the Rule of Law, i.e. those affected by a decision should have a say in it. Thus, the relationship between those affected and global administrative bodies under GAL is idealised as one of accountability, not hypothetical consent not sovereignty. This can be traced to GAL's genesis in domestic administrative law, where fairness and decision quality are the primary reasons for the creation of participation mechanisms and not the need for democratic consent, which is largely transmitted through electoral mechanisms

\footnotetext{
115 Or as Wheatley puts it, there is no such thing as illegitimate authority.

${ }^{116}$ Wheatley, "Democratic Legitimacy", supra note 7 at 313-314.
} 
The divergence in rationale for participation may be of limited relevance where the two theories - GAL and global deliberative democracy - concur on the form of participation that is required for democracy and accountability. However, I contend that this difference has implications for the debate over the nature and extent of participation required. I suggest this debate may be structured in a fundamentally different way under GAL and global deliberative democracy and in particular the participation of non-state actors under global deliberative democracy will have greater significant due to the need for consent and the role of those actors as authors of norms.

\subsubsection{Similarities}

While there are dissimilarities regarding aim and in the justifications for participation, there is common ground between GAL and global deliberative democracy regarding the need for participation.

Participation is essential to deliberative democracy and global deliberative democracy. In the deliberative model, "[l]aws are valid only where all possibly affected persons could agree as participants in rational discourses" (my emphasis). ${ }^{117}$ Participation reflects the underlying discursive process; without it deliberation is non-existent. Similarly, GAL prizes participation; in the original definition, participation was listed as one of the key means for promoting accountability and a range of mechanisms for examined. GAL scholars have subsequently explored the possibilities for participation in diverse areas from earth system governance ${ }^{118}$ to the creation of banking standards. ${ }^{119}$ More generally, Nirmalya Syam notes that the traditional understanding of administrative law is seen as enhancing deliberative democracy in administrative decision-making, although he warns this value may be limited when applied to global institutions. ${ }^{120}$

Therefore, the shared support of participation and deliberation by GAL and global deliberative democracy requires closer examination. One of the main issues is that participation is an

\footnotetext{
${ }^{117}$ Wheatley, "Democratic Law", supra note 103 at 535.

${ }^{118}$ Francesca Spagnuolo, "Diversity and pluralism in earth system governance: Contemplating the role for global administrative law" (2011) 70 Ecological Economics 1875.

${ }^{119}$ Michael S. Barr \& Geoffrey P. Miller "Global Administrative Law: The View from Basel” 17 EJIL 15.

${ }^{120}$ Nirmalya Syam, Civil Society Groups and Administrative Law: An Amicus Curiae in WTO (New York: Institute for International Law and Justice, 2007) at 5.
} 
ambiguous principle in its conceptualisation and application. ${ }^{121}$ Within global deliberative democracy, participation is a right for all people subjected to a global regime ${ }^{122}$ and may be exercised directly or through representatives, ${ }^{123}$ such as assemblies, through a constitutional framework. While GAL scholarship has underscored the importance of participation and proposed various means of enhancing non-state actor participation, the type of participation promoted is largely indirect and ad-hoc.

\subsubsection{Engaging with deliberative democracy}

A consideration of key similarities and differences reveals substantial consistency between GAL and global deliberative democracy; however, I suggest there are significant barriers from GAL adopting global deliberative democracy.

Firstly, there are several features of global deliberative democracy that GAL pointedly excludes or omits examination. For example, under global deliberative democracy, global regulation should be consistent with international human rights standards ${ }^{124}$. GAL scholarship has rarely explored human rights as a guiding tool or principle in application to international organisations. $^{125}$ The creation of elected assemblies at international organisations that global deliberative democracy promotes is another example of a grander normative project that the GAL vision rejects.

Furthermore, GAL scholars have discredited the ability of deliberative models to deliver democratic authority. Kingsbury, Krisch, and Stewart argued that deliberative democracy has problems defining "the public" in global governance ${ }^{126}$ and in designing appropriate mechanisms of global participation. ${ }^{127}$ Where global regulatory administrative intensifies and involves major distribution issues, they contend deliberative democracy will lack democratic

\footnotetext{
${ }^{121}$ Harlow, supra note 39 at 193.

${ }^{122}$ Wheatley, Democratic Legitimacy, supra note 7 at 317.

${ }^{123}$ Ibid at 332.

${ }^{124}$ Ibid.

${ }^{125}$ Benedict Kingsbury \& Lorenzo Casini, "Global Administrative Law Dimensions of International Organizations Law” (2009) 6 International Organizations Law Review 319 at 339-340.

${ }^{126}$ Although as I explored above, Wheatley has subsequently attempted to overcome this issue by advocating 'those subject to a particular regulatory regime' as the appropriate definition of the political community.

${ }^{127}$ Kingsbury, Stewart \& Krisch, supra note 25 at 49.
} 
credentials without a sufficient connection to the "the public". ${ }^{128}$ Stewart has separately cautioned against apotheosizing participation, stating that "expanded participation is not a cureall for global governance failures" and "[e]xtending decisional authority to representatives of general social and economic interests is often politically infeasible or operationally impracticable". 129

However, Kingsbury and Stewart have in yet another separate article appeared more optimistic, suggesting "global administrative law might also support the development of deliberative democracy at the level of global regulatory regimes, although the elements of such a conception as well as the conditions of its effective realization have yet to be resolved". ${ }^{130}$ Thus, GAL scholars may be cautious, at least without further theorisation, in suggesting that GAL adopt deliberative democracy, particularly where it is promoted as the sole means of legitimisation.

The Codex Commission and New Zealand Food Bill case study help to illustrate the conceptual and practical issues in GAL engaging with global deliberative democracy. At present, the Codex Commission allows for the participation NGOs who are awarded "observer status". Having observer status provides the ability to send an observer to sessions of the Codex Commission and subsidiary bodies, receive working papers and documentation, and submit written statements. ${ }^{131}$ However, it does not provide for a right to vote. State members and their delegations have a full complement of participation rights including voting. Individuals who are not affiliated to a NGO or a state party do not have any rights.

Under the global deliberative democracy model, the standards of the Codex Commission relevant to the New Zealand Food Bill (and generally) arguably do not have sufficient democratic legitimacy. There is no right of direct participation for New Zealanders subject to the

\footnotetext{
${ }^{128}$ Ibid.

${ }^{129}$ Richard B. Stewart, “Accountability, Participation, and the Problem of Disregard in Global Regulatory Governance" (International Legal Theory Colloquium on Interpretation and Judgement in International Law Paper delivered at New York University Law School, 7 February 2008) at 3.

${ }^{130}$ Benedict Kingsbury \& Richard B. Stewart, "Legitimacy and Accountability in Global Regulatory Governance: The Emerging Global Administrative Law and the Design and Operation of Administrative Tribunals of International Organisations" in K Papanikolaou \& M Hiskaki, eds, International Administrative Tribunals in a Changing World (London: Esperia, 2008) 1 at 14.

${ }^{131}$ Principles concerning the participation of International Non-Governmental Organizations in the work of the Codex Alimentarius Commission at 5.1.
} 
food-standards regime. The representation of all interests is unlikely given the problems of unequal participation that have been analysed by Chimni and Livermore. Nor is there an elected representative assembly within the Codex Commission with a New Zealand member. Participation by New Zealand in the Codex Commission activities is managed by the New Zealand Ministry for Primary Industries, ${ }^{132}$ whose 13 page document "New Zealand's Strategic Objectives in Codex" contains two paragraphs on non-state participation, stating that its policy is to "[c]onsult all interested parties" and "[i]mprove stakeholder knowledge and understanding of Codex". Given the lack of knowledge regarding the Codex Commission and concerns over corporate influence in the Food Bill it is hard to argue that these goals have been met and the representation of all New Zealand interests and perspectives to the Codex Commission has been made.

Under the global deliberative democracy vision, all those subjected to the food-safety regime in New Zealand (and elsewhere) of the Codex Commission must have a right direct or indirect participation. This may require allowing individual New Zealanders to make submissions on drafts or provide for greater NGO representation of consumer and small-producer interests by reserving funding or incorporating permanent institutions for civil society engagement. Decision-making may also have to be fundamentally re-structured with an elected assembly replacing member representatives and the current 7 step standard-setting process revised to ensure.

More fundamentally, the Codex Commission would have to elucidate reasoning that is understandable and supported by those subject to the regime in New Zealand and to provide interest-based deliberation that is not privileged. This, I submit, would involve substantial institutional, legal, and cultural change.

In contradistinction, GAL offers much less ambitious arrangements that consciously reject or exclude 'parliamentarisation'. While the GAL approach identifies similar deficits in the Codex Commission's decision-making, its prescription is more modest. We saw Livermore propose the WTO Appellate Body extend its remit to (procedurally) review Codex Commission standards.

\footnotetext{
${ }^{132}$ Formerly it was the New Zealand Food Safety Authority under the remit of the Ministry of Agriculture and Forestry; however both these entities merged with Ministry of Fisheries to form a 'super' ministry in April 2012.
} 
Bevilacqua, adopting the GAL approach, has argued increasing transparency of the Codex Commission would achieve a better public understanding, a greater link between decisionmakers and takers, and increase accountability. However, he acknowledges this is only one element of the Habermas's procedural (democratic) legitimacy; judicial review and enhanced participation would also be required. ${ }^{133}$

So we see both global deliberative democracy and GAL would offer similar analysis on the Codex Commission and the New Zealand Food Bill but constraints on the latter adopting or promoting the former remain in the attitude of some GAL scholars to deliberative democracy, the depth of participation and deliberation required, and the need for a representative assembly.

In sum, GAL shares some consistency with global deliberative democracy but it does not represent it and there remain significant barriers to its full adoption. However, it does provide some opportunities if conceptual and normative amendments were made. GAL could adopt the "subjected-to" standard as the criterion for participation in decision-making and Wheatley's delineation of the demos by reference to the exercise of authority. This may provide the appropriate link for between global administration and "the public". More generally, GAL would have to embed values of deliberative democracy such as equality and public reason to a greater degree. GAL would also have to reorient itself to view deliberation and participation as the primarily a tool not only for accountability but (discursive) democracy. More difficult conceptual adjustments would have to be made in endorsing the creation of representative and electoral assemblies and the role of human rights standards as well as shedding its reluctance to endorse grander normative projects that offer a fully-elaborated vision and justification of global governance.

\subsection{Cosmopolitan Democracy}

\subsubsection{What is cosmopolitan democracy}

The theory of cosmopolitan democracy I analyse is primarily that of David Held and Daniele Archibugi, with emphasis on Archibugi's full theorisation in The Global Commonwealth of Citizens. Archibugi defines cosmopolitan democracy is as "a project of normative political

\footnotetext{
${ }^{133}$ Bevilacqua, supra note 45at 18.
} 
theory that attempts to apply some of the principles, values, and procedures of democracy to the global political system". 134

Its antecedents are traced to early theoretical responses to globalisation. In 1995 Archibugi and Held published Cosmopolitan Democracy: An Agenda for a New World Order, the first booklength elaboration of their new theory. They argued that the nature and prospects of democracy had been radically altered by globalisation. The locus of political power no longer resided in national governments and 'political communities of fate' were no longer delimited by territorial boundaries. $^{135}$ As a result, its proponents argued, of the over-lapping communities of fate and closely entwined fortunes for states and societies, democratic thought faced several dilemmas. ${ }^{136}$ Standard democratic questions, such as what is the relevant constituency, whose consent and participation is needed in decisions, and to whom should decision-makers be accountable no longer anticipated conclusive answers.

For cosmopolitan democrats, the solution to this impasse lay not in promoting a different system of governance; democracy remained the sole source of authority and power. However, theorists of cosmopolitan democracy sought to reimagine democracy to address this "crisis of legitimacy" 137 that had been caused by the loss of state autonomy and the increasing complex interdependency and connectedness of the world. Archibugi rearticulated democracy as a process rather than a set of norms and procedures. ${ }^{138}$ The process of democracy, he wrote, is neither static nor unfinished, but rather an endless project or path. ${ }^{139}$ His process-orientated

\footnotetext{
${ }^{134}$ Daniele Archibugi, "Cosmopolitan democracy: a restatement” (2012) 42 Cambridge Journal of Education 9 at 9 [Archibugi, "Restatement"].

135 David Held, “Democracy and Globalization” (1997) 3 Global Governance 251 at 260-261 [Held, "Globalization"].

${ }^{136}$ Ibid.

${ }^{137}$ David Held, "Democracy and the New International Order" in Daniele Archibugi \& David Held, eds., Cosmopolitan Democracy: An Agenda for a New World Order (Cambridge, England: Polity Press, 1995) 97 at 102 [Held, "New Order"].

${ }^{138}$ Daniele Archibugi, "Cosmopolitan Democracy and its Critics: A Review" (2004) 10 European Journal of International Relations 437 at 439 [Archibugi, "Critics"].

${ }^{139}$ Ibid at 439-440.
} 
conceptualisation of cosmopolitan democracy shares several liberal values and principles including equality, dignity, accountability, consent, and participation. ${ }^{140}$

In terms of institutional architecture, cosmopolitan democracy proposes several (often radical) proposals. Foremost, cosmopolitan democracy not only seeks to remodel global governance, but is a complete democratic theorisation that applies at five paradigmatic levels of governance (not government): local, state, inter-state, regional, and global. ${ }^{141}$ The framework to provide this proposes an association of (existing) states somewhere between a confederation (such as NATO) and a federation (such as Germany). Thus, cosmopolitan democracy shies away from an overly centralised global order, suggesting instead a mixture of integration and reform of the existing sub- and supra- state structure with several new institutions. ${ }^{142}$

Perhaps unsurprising, reform of the UN is a keystone of the cosmopolitan democracy project. Archibugi recommends a slew of reforms including making the Security Council more equitable and representative, democratising the appointment of individual UN General Assembly representatives and amending its voting procedures, and making the jurisdiction of the International Court of Justice compulsory and providing non-state actors with enhanced standing. Related to this, cosmopolitan democracy also proposes the establishment of regional parliaments and a world parliament with members directly elected by world citizens.

Given the proliferation of political actors and the spatial demarcation of governance, the relationship between the different levels of governance and institutions is critical to cosmopolitan democracy. However, it emphatically rejects the existing approach to the distribution of political power based on sovereignty. ${ }^{143}$ Archibugi considers constitutionalism offers a better model to allocate competencies and resolve conflicts, suggesting a global constitution which would mandate judicial adjudication on the distribution of power.

\footnotetext{
${ }^{140}$ David Held, "Restructuring Global Governance: Cosmopolitanism, Democracy and the Global Order" (2009) 37 Millennium: Journal of International Studies 535 at 538 [Held, "Restructuring Global Governance"].

${ }^{141}$ Daniele Archibugi, The Global Commonwealth of Citizens (Princeton: Princeton University Press, 2008) at 89 [Archibugi, "Global Commonwealth"].

${ }^{142}$ Ibid at 110 .

${ }^{143}$ Ibid at 98.
} 
Two further features are relevant to my discussion - the endowment of a world citizenship and the development of a cosmopolitan law. I discuss these further below; here I note the transformation of individuals as global right bearers under world citizenship and the formation of a new legal framework by cosmopolitan law are salient features of the cosmopolitan democracy project.

This brief overview of cosmopolitan democracy illustrates that it recognises the growth of nonstate sources of political power and the inter-connectedness of the world, emphasising in response the need for citizen participation and empowerment and enhanced transnational cooperation through multi-level governance.

\subsubsection{Differences}

I suggest there are three important points of divergence between GAL and cosmopolitan democracy, namely in their aims, attitude to global governance, and view of democracy and legitimisation.

We saw in Krisch's discussion and justification for bracketing democracy that GAL does not seek to rearticulate and justify a new world order on a democratic basis, but to develop specific mechanisms to enhance the accountability of global administration. Its aim therefore is relatively limited. In contrast, cosmopolitan democracy aims far higher; it does seek to justify and elaborate a new (reformed) global order on the basis of democracy. In Archibugi's words, cosmopolitan democracy aims "to achieve a world order based on the rule of law and democracy". 144

The aims of cosmopolitan democracy are also far broader than those of GAL. Cosmopolitan democracy seeks to implement democratic ideals on multiple levels - from local to global governance. Archibugi notes that "the democratization of global governance is... one of the main objectives of cosmopolitan democracy [although] not the only one". ${ }^{145}$ In contradistinction, GAL aims to promote the accountability of global administrative bodies operating in the global

\footnotetext{
${ }^{144}$ Daniele Archibugi, "Principles of Cosmopolitan Democracy" in Daniele Archibugi, David Held \& Martin Köhler, eds, Re-imagining Political Community (Cambridge, England: Polity Press, 1998) 198 at 198.

145 Archibugi, "Restatement", supra note 134 at 12.
} 
administrative space, roughly equivalent to global governance. It does not aim to enhance the accountability of local or state bodies, ${ }^{146}$ although it seeks to ensure the participation of local communities in global decision-making.

In addition, the 'legal' component of cosmopolitan democracy has far more significant aims than that of GAL In particular, both Held and Archibugi propose a move to cosmopolitan law based on the Kantian ideal. Distinct from (though alongside) traditional "inter-state" law, cosmopolitan law applies globally and directly to citizens. In this manner, Archibugi suggests the inclusion, inter alia, of (international) environmental law and humanitarian law as part of cosmopolitan law. ${ }^{147}$ This aim goes beyond a semantic change of term for international law or a recognition that globalisation has significant impact on international law. ${ }^{148}$ It represents an entirely new legal framework with new actors, participants, mechanisms of enforcement, subject matter, and legitimisation.

GAL does not seek such a radical overhaul of international law, simply to map existing practices (law based on the Hartian social fact criteria) of global bodies and propose further mechanisms for accountability. While acknowledging the direct impact of global administrative norms and decision-making, GAL does not aim to establish and legitimate a new legal order, but to map existing global administrative structures and patterns.

The second main difference concerns the attitude of GAL and cosmopolitan democracy to the role of global governance. Cosmopolitan democracy has a fundamental belief in the necessity and rightness of global governance. While the view is not uncritical - it critiques global governance and seeks to transform it - it values it as integral to the development of democracy and the delivery of social goods. For example, Archibugi considers that the UN is "the pivot of

\footnotetext{
${ }^{146}$ Except where they form part of the network of component of a global administrative body; but there the aim is not to promote the accountability of the state actor as such, but its participation or role in global administration.

${ }^{147}$ Archibugi, "Global Commonwealth", supra note 141 at 120.

${ }^{148}$ See Frédéric Mégret, "Globalization” in R. Wolfrum (ed), The Max Planck Encyclopaedia of Public International Law (Oxford University Press, 2008)

Online: OUP <http://www.mpepil.com/subscriber_article?script=yes\&id=/epil/entries/law-9780199231690e939\&recno=1\&author=M\%C3\%A9gret\%20\%20Fr\%C3\%A9d\%C3\%A9ric $>$.
} 
the entire world judicial and political system" $" 149$ while simultaneously providing extensive critiques and suggestion for reform.

I contend that GAL scholarship approaches global governance with a more sceptical eye. Krisch himself acknowledges this, suggesting that the GAL focus on accountability and the potential constraints of existing institutions may overemphasises their threat at the cost of more positive views that see global governance as a means for self-government or non-domination. ${ }^{150}$

This attitude towards global governance can be usefully illustrated through administrative law theories. The Green light approach to administrative law views it its role in helping to assist the state meet policy objectives and provide justice and policy efficiency. Similarly, cosmopolitan democracy, as an 'enabling' theory, aims at reinforcing global governance in order to meet social and economic objectives yet also concerns itself with (democratic) fairness and efficiency. The Red light approach to administrative law views the state (government) as dangerous to individual liberty and contends it is the role of the judges to protect against this. GAL implicates a Red light approach to global governance by focusing on the need to curb or constrain global administration in order to protect individuals ${ }^{151}$ and emphasising judicial remedies such as review.

I suggest these dissimilarities of aim and attitude may indicate substantial inconsistency between GAL and cosmopolitan democracy. Cosmopolitan democratic theorists propose the creation of several institutions, such as regional parliaments and a global parliament, to deliver social goods and enhance democracy, while GAL is reluctant to embrace large-scale institutional creation. This does not point to an impermeable inconsistency of GAL with cosmopolitan democracy but it may indicate a normative rubicon for GAL scholars regarding new large-scale institutional creation where they would state "this far - no more" to cosmopolitan democracy.

\footnotetext{
${ }^{149}$ Archibugi, "Global Commonwealth", supra note 141 at 156.

${ }^{150}$ Krisch, "GAL Ambition", supra note 68 at 260.

${ }^{151}$ In their original article, Kingsbury, Krisch, and Stewart do consider whether protecting individual rights can serve as the appropriate normative basis for GAL. Ultimately, they consider it may pose too many difficulties as it presupposes a priority of liberal values that is inconsistent with a pluralist world order. Nonetheless, I argue that subsequent scholarship, including by Krisch, establish a strong focus on constraining of global governance and the protection of individual (including corporate) rights.
} 
The last major difference I highlight concerns democracy and legitimisation. Cosmopolitan democracy posits democracy as the sole and only legitimisation for political power and (including global) governance and highlights the importance of electoral democracy. Cosmopolitan democrats enunciated a "crisis of legitimisation" in response to globalisation not because there was a paucity of concepts of ideas to legitimise governance but due to the inability of existing political theory and practice to apply democracy to new political structures. Democracy, although mutating and unfinished in the cosmopolitan democratic view, remains the apogee of political values and normative resource to the cosmopolitan democrat; it provides the ultimate source of legitimating politics and governance.

At variance with this, GAL challenges the privileging of (particularly electoral) democracy as the sole or ultimate source of legitimising governance. Its scholars have elaborated a broader and more nuanced understanding of legitimacy. Esty, an early GAL adherent, has proposed six types of legitimacy - democratic, results-based, order-derived, systemic, deliberative, and procedural - and suggests legitimacy in global governance can come through several means. ${ }^{152}$ Kate and Terry Macdonald, political scientists adopting a GAL approach, have argued democracy accountability can be secured via non-electoral mechanisms that perform equivalent functions. ${ }^{153}$ Andreas Follesdal, a cosmopolitan democrat, has explicitly rejected the possibility for democratic accountability through non-majoritarian electoral mechanisms because these alternatives (including Terry and Kate Macdonald's model) are not sufficiently responsive and engender other demarcation problems. ${ }^{154}$

The exact nature of the legitimisation generated by GAL is contested. Kingsbury and Stewart comment that the rules of GAL "can be of considerable significance in framing, vindicating and cabining concepts of legitimacy and accountability", ${ }^{155}$ although they do not explicate the exact basis for the legitimacy GAL provides. Euan Macdonald contends that one of GAL's core

\footnotetext{
${ }^{152}$ Esty, supra note 81 at $1509-1523$.

${ }^{153}$ Terry Macdonald \& Kate Macdonald, "Non-Electoral Accountability in Global Politics: Strengthening Democratic Control within the Global Garment Industry" (2006) 17 EJIL 89.

${ }^{154}$ (Andreas Follesdal, "Cosmopolitan democracy: Neither a category mistake nor a categorical imperative" in Daniele Archibugi, Mathias Koenig-Archibugi \& Raffaele Marchetti, eds, Global Democracy: Normative and Empirical Perspectives (New York: Cambridge University Press, 2012) 96 at 109-111).

${ }^{155}$ Kingsbury \& Stewart, supra note 130 at 10.
} 
insights is that "legitimacy can be improved by increasing the responsiveness of global governance bodies to the interests of those upon whom their activities impact" and locates the legitimacy of GAL in an appeal to fairness and/or individual rights. ${ }^{156} \mathrm{Kuo}$, a critic of GAL theorisation, has argued its legitimacy is based on post-publicness, which turns out to be a privatisation of legitimacy. ${ }^{157}$

Here my point is not to determine who is correct, but to highlight the different approaches to legitimisation offered by GAL and cosmopolitan democracy. It would be an overstatement to indicate a polarity of approaches to legitimisation. Accountability, transparency, participation all principles central to the promotion of accountability and the legitimisation of GAL - are also promoted by cosmopolitan democracy. But the differences in legitimisation do matter, in a search for legitimisation of global governance GAL and cosmopolitan democracy the divergence in approach presents considerable problems of conflicting values and techniques.

\subsubsection{Similarities}

I turn now to examine the similarities between GAL and cosmopolitan democracy and argue there are two salient commonalities - the embracement of pluralism and the framework for understanding global governance.

As I briefly summarised in section 2, many GAL theorists have proposed and promoted a pluralist approach. Harlow assessed four potential sources of values and principles of GAL, but concluded that pluralism and diversity of values was preferable in the face of universality. ${ }^{158}$ In a related vein, Krisch strongly argued for a pluralist order regarding the constituencies of global governance. $^{159}$.

\footnotetext{
${ }^{156}$ Euan Macdonald, A little more on networks... (28 January 2009), online: Global Administrative Law <http://globaladminlaw.blogspot.ca/2009/01/little-more-on-networks.html>.

${ }^{157}$ Ming-Sung Kuo, "Taming Governance With Legality? Critical Reflections Upon Global Administrative Law as Small-c Global Constitutionalism" (2011) 44 NYUJ Int'1 L \& Poly 55 at 62.

${ }^{158}$ Harlow, supra note 39.

${ }^{159}$ Krisch, "Pluralism", supra note 40 at 269.
} 
Similarly, Held has argued that "modern cosmopolitanism acknowledges a plurality of values and moral conceptions of the good". 160 The pluralism at work here is the promotion of an underlying framework that allows, within certain boundaries, the attachment and practice of a variety of values and principles. It is also one that recognises the diversity of values is a key issue any trans-national theory of governance has to face.

I also suggest that GAL and cosmopolitan democracy share a similar view and framework for understanding globalisation and global governance. For instance, both GAL and cosmopolitan democracy have interpreted the structures and impact of globalisation in a common light. GAL conceives of global governance as operating in a less structured environment ${ }^{161}$ that is "extraordinarily varied" and multi-layered ${ }^{162}$ and highlights the numerous extra-state sites of public power that have been created through globalisation. Cosmopolitan democracy shares this lens. It has pointed to a raft of new forms of transnational political organisation ${ }^{163}$ that is diffuse and overlapping. ${ }^{164}$

However, as I argued in section 2, GAL conceptualises this governance in a narrow fashion, namely, administration. Nonetheless, the importance of a shared diagnosis (if not labelling) of an emerging post-Westphalian political and legal order is a commonality that should not be overlooked. It provides opportunities for GAL to adopt or incorporate cosmopolitan democratic analysis and ideas on the nature and character of global governance and the post-Westphalian order because their articulations are largely consistent.

\subsubsection{Engagement with cosmopolitan democracy}

I argue that despite a divergence of aims, GAL may already be reflecting certain features of the cosmopolitan democratic vision and it may be possible for GAL to enhance this connection and engage with cosmopolitan democracy, although substantial a gap exists between the limited normative theorising of its scholars and the latter's grander project. Thus, one should be careful

\footnotetext{
${ }^{160}$ Held, "Restructuring Global Governance", supra note 140 at 539.

${ }^{161}$ Chesterman, supra note 66at 80.

${ }^{162}$ Kingsbury, Krisch \& Stewart, supra note 25 at 19.

${ }^{163}$ Held, "Globalization", supra note 135 at 259.

${ }^{164}$ Held, "Restructuring Global Governance", supra note 140 at 544.
} 
to attribute too much value to the democratic legitimisation provided by GAL under a cosmopolitan democratic framework.

My first point is that there may already be substantial consistency between GAL and cosmopolitan democracy because the latter integrates GAL projects in its vision. Paradigmatically, cosmopolitan democracy encourages a small-step approach to reform. Archibugi acknowledges the grand ambition of cosmopolitan democracy, but states that this "should not hide that its politics is rooted in daily campaigns and that there are a number of small and progressive targets that can be achieved". ${ }^{165}$ The principal object of cosmopolitan democracy, Archibugi claims, is to provide a framework for these campaigns. He lists campaigns for greater accountability ${ }^{166}$, the Rule of Law, and participation of stake-holders ${ }^{167}$ as part of the global dimension of cosmopolitan democracy. Campaigns that could include GAL projects such as enhancing the promoting the transparency of the WTO system, promoting the Rule of Law in the War on Terror, ${ }^{168}$ and enhancing the participation rights of indigenous people in mining decisions. ${ }^{169}$

Accountability also rates highly on the cosmopolitan democratic agenda. Held has underscored the accountability deficits in global governance that need to be addressed $-{ }^{170}$ the raison d'être of GAL. In his earlier theorising, Held also posited short-term goals of reform based on participation, representativeness, and accountability. Thus, arguably GAL is part of the seeds of an emergent cosmopolitan democratic framework and already internalises and expresses elements of a nascent (global) democracy.

\footnotetext{
165 Archibugi, "Restatement", supra note 134 at 15.

166 Ibid at 14 .

${ }^{167}$ Ibid at 15

${ }^{168}$ See Mario Savino, "The War on Terror and the Rule of Law" in Sabino Cassese, Burno Carotti, Lorenzo Casini, Marcho Macchia, Euan MacDonald, and Mario Savino, eds, Global Administrative Law: Cases, Materials, Issues, 2d ed (New York: Institute for Research on Public Administration, Institute for International Law and Justice, 2008) 109.

${ }^{169}$ See Gian Luca, "Participation of Indigenous People: The Guatemala Marlin Gold Mine" in Sabino Cassese, Burno Carotti, Lorenzo Casini, Marcho Macchia, Euan MacDonald, and Mario Savino, eds, Global Administrative Law: Cases, Materials, Issues, $2 \mathrm{~d}$ ed (New York: Institute for Research on Public Administration, Institute for International Law and Justice, 2008) 133.

${ }^{170}$ Held, "Restructuring Global Governance", supra note 140 at 544
} 
A consideration of the alternative visions provided by GAL and cosmopolitan democracy regarding the Codex Commission and the New Zealand Food Bill assists in revealing the possibilities for GAL to integrate or reflect cosmopolitan democracy. As I explored above with deliberative democracy, GAL offers a limited reform of the Codex Commission in response to the concerns of New Zealanders regarding the Food Bill. Livermore argues that a judicial review of process would assist participation and Bevilacqua encourages increased transparency to enhance accountability. Both offer limited reforms that are, to apply Archibugi's thinking, daily campaigns aimed at small and progressive targets.

A cosmopolitan democratic approach to the New Zealand Food Bill would analyse the need for democracy within the Codex Commission as well as in local and state governance of New Zealand. Thus, it would analyse the implementation and enforcement of food-standards by local authorities and promote the strengthen participation by affected New Zealand communities in this governance, perhaps by regular establishing regular working groups. It would consider the quality and quantity of consultation by the Ministry for Primary Industries in New Zealand regarding the Codex Commission's standard-setting and emphasise the need to contextualise such consultation within broader trans-national groups who have similar interests, for example small-food producers in the South Pacific.

A cosmopolitan democratic approach would also enforce and promote participation of affected New Zealand individuals in decision-making of the Codex Commission. Perhaps most significantly, cosmopolitan democracy would investigate the wider role and context of the Codex Commission in the global order. In particular, it would advocate the creation of a World Parliament that may have direct or indirect control over the law-making of the Codex Commission in setting food-safety standards perhaps through review or an approval mechanism. I also suggest the linkage between the Codex Commission and the WTO via the SPS Agreement and the economic imperatives to for member states to conform to the Codex Commission's standards would come under close scrutiny. Economic disparity issues such as this receive little to no attention in the GAL analysis despite the links established in democratic states between low socio-economic status and political disenfranchisement.

Thus, I caution against overestimating the consistency between GAL and cosmopolitan democracy and the subsequent possibility for GAL to promote or absorb the latter. There 
significant conceptual barriers. Firstly, GAL rejects the likelihood of more ambitious aims such as a world parliament. Krisch warns that Global constitutionalism would require comprehensive reconstruction that would necessitate massive institutional change and a transformation of the global order. ${ }^{171}$ This scepticism would place GAL at odds with the broader cosmopolitan democratic ideal. It may also be that the shared commitment to accountability-enhancing campaigns between GAL and cosmopolitan democracy is less conceptual affinity than happenstance.

There is also risk in locating GAL in its present form within the cosmopolitan democratic project or by GAL scholars referencing broader cosmopolitan democratic connections. If GAL seeks to displace democratic seeking critics, such as Marks, by highlighting consistency with cosmopolitan democracy (i.e. by saying it is part of a democratic vanguard) this position may further legitimise GAL on cosmopolitan democracy grounds despite it rejecting the broader aims of its broader project. In other words, GAL might be having one's cake and eating it too.

Therefore, for GAL to fully engage with cosmopolitan democracy it GAL scholars would have to enunciate a greater belief in global democracy (including a world parliament) along cosmopolitan democratic lines. This would not necessarily require denying its idealistic nature, but subscribing to a positive view of its potential. It would also require GAL to delimit and reprioritise its legitimising potential in a more explicit manner. Thus, where Esty claims six types of legitimisation and GAL scholars point to the potential of accountability; this would have to be prefaced on the privileging of democratic legitimisation over other types of legitimisations.

Finally, it would require GAL scholars to explicitly acknowledge the normative superiority of the cosmopolitan democratic project and locate their role within that broader umbrella. The benefit of GAL adopting a cosmopolitan democracy banner is that the explicitly limited aims of GAL could be retained, provided an explicit espousal of cosmopolitan democracy is made and a great contextualised account of itself within that project is undertaken.

\footnotetext{
${ }^{171}$ Krisch, "GAL Ambition”, supra note 68 at 254.
} 


\subsection{Radical democratic pluralism}

I now consider the third and final theory of global democracy, radical democratic pluralism. I argue that there exists large inconsistency between GAL and radical democratic pluralism; in particular, I suggest this theory of democracy illustrates the institutional conservatism and realism underpinning GAL scholarship's reluctance to engage with democracy. Thus, for GAL to engage with radical democratic pluralism would require thoroughgoing theoretical and practical change.

As a preface, I note radical democratic pluralism is deeply heterogeneous; it may be more properly viewed as a broad approach to (global) democracy in contrast to the more unitary nature of deliberative and cosmopolitan democracy theories. While these latter theories are not without internal disputes, radical democratic pluralism rests on a smaller consensus amongst its proponents and does not elucidate a fully elaborated, institutional vision of global democracy. As such, I draw on the common features of its proponents as well as secondary commentary to explore it. However, despite its conceptual dissonance (exemplified by the fact its scholars ascribe varying labels to their theories), I believe it provides a valuable and worthwhile counterpoint to deliberative and cosmopolitan democracy, one that exposes GAL to a powerful critique and reveals certain underlying assumptions.

\subsubsection{What is radical democratic pluralism}

Radical democratic pluralism is the term given to a number of related approaches to democracy that expound a critical and radical model. It is best understood as an amalgam of a several critiques and theories of democracy. Hutchings, an international relations theorist, describes it as "cocktail of elements of postmodernist, Marxist and civic republican democratic theory". ${ }^{172}$ Its main authors are Walker, Burnheim, Connolly, Mouffe, and more recently Patomäki; however, the diversity of these authors reflects the amalgamated nature of radical democratic pluralism. As such, Patomäki refers to himself as a critical realist and labels Connolly and Walker Poststructuralist. $^{173}$

\footnotetext{
${ }^{172}$ Kimberly Hutchings, International political theory: rethinking ethics in a global era (London: SAGE, 1999) at 167.

${ }^{173}$ Heikki Patomäki, "Global Democracy” (2006) 23 Theory, Culture \& Society 519 at 520.
} 
At its heart radical democratic pluralism promotes the creation of alternative sites and forums for democracy at all levels (local to global) that practice direct democracy and self-governance. ${ }^{174}$ Its vision implicates the creation of alternative sites for political organisation largely outside established mechanisms of state and international law. ${ }^{175}$ Its scholars build on the normative and practical perspectives of new social movements in global governance and promote the strengthening of global civil society and 'grass-roots' organisations. ${ }^{176}$ Overall, radical democratic pluralism advocates a new type of politics centred on the empowerment of individuals and communities. ${ }^{177}$ This is an unreservedly a bottom-up approach, asserting the priority of the meaningful and direct participation of people in decision-making. ${ }^{178}$

As such, it seeks to disrupt and displace traditional source of democratic legitimacy, such as state sovereignty, in the favour of new forums and modes. This vision is antipathetic to the dominating positive interpretation given to the spread of liberal democracy and free market capitalism through globalisation. It remains captious of new global governance as an unaccountable, elite form of "geo-governance" from above. ${ }^{179}$ At first glance radical democratic pluralism appears is synonymous with the 'anti-globalisation' movement in its rejection of the 'Washington consensus'. However, some argue that "alterglobalisation", which characterises the anarchical forms of protest against the 'Washington consensus' and globalisation movement represents a challenge to radical democracy. ${ }^{180}$

Thus, what the radical democratic pluralists have in common is an attachment to direct and participatory democracy, a critique of the neo-liberal world order, and a strong focus on the individual and community as central actors in global society. They hold that real (global)

\footnotetext{
${ }^{174}$ Anthony McGrew, "Models of Transnational Democracy" in David Held \& Anthony McGrew, eds, The Global Transformations Reader (Cambridge, England: Polity Press, 2003) 500 at 501.

${ }^{175}$ Hutchings, supra note 172 at 166.

${ }^{176}$ Ibid at 167.

${ }^{177}$ McGrew, "Models", supra note 174 at 502.

${ }^{178}$ Jost Delbrück, "Exercising Public Authority Beyond the State: Transnational Democracy and/or Alternative Legitimation Strategies?” (2003) 10 Ind J Global Legal Stud 29 at 38.

${ }^{179}$ Hutchings, supra note 172 at 167.

${ }^{180}$ Daniel Murray, "Democratic Insurrection, Or, What does the alterglobalization movement have in common?" (Paper delivered at the Anarchist Studies Network Conference, University of Bristol, England, 17 June 2010) [unpublished].
} 
democracy rests in the juxtaposition of numerous self-governing and self-organising collectives from local to global. ${ }^{181}$ Mouffe has taken a post-Marxist account of democracy that seeks to not to reject liberal democracy, but to "deepen and expand it in the direction of a radical and plural democracy". ${ }^{182}$ She advocates an "agonistic model" of democracy that acknowledges conflict as ineradicable and inherent in society, but promotes liberal democratic institutions to acknowledge and allow expression of these differences in a agonistic manner rather than purporting to ascertain an apocryphal 'consensus'. 183

Walker criticises the assumed spatial and temporal links between democracy and the state, arguing that for democracy to flourish new political spaces need to be opened. . Connolly, sharing some of the concerns of GAL scholars, critiques the universalist ambitions of projects such as cosmopolitan democracy. He is sceptical of 'blueprint' approaches to global democracy; instead advancing an interpretation of global democracy as a culture or ethos of disturbance that advocates respect for multiple constituencies and rejects foundational norms. ${ }^{184} \mathrm{He}$ considers that the politics of disturbance should be mobilised by those "democratic energies already exceeding the boundaries of the state". 185

Democratic radical pluralism promotes a largely theoretical approach and suffers an 'institutional deficiency'. ${ }^{186}$ This can make it difficult to engagement with GAL on an academic level; however, despite the lack of reification, I argue that there is sufficient 'meat' to analyse. Indeed, some authors within this approach provide deeper institutional suggestions. Patomäki has elaborated a developed concrete range of reforms and new institutions for global democracy including a world parliament, global tax, binding jurisdiction of the ICJ, an enhanced World Social Forum for NGOs as well as "a quest for transparency, accountability and full participation in the decision-making process by all states and global civil society actors" in the IMF, World

\footnotetext{
${ }^{181}$ Anthony McGrew, "Transnational democracy" in April Carter \& Geoffrey Stokes, eds, Democratic Theory Today: Challenges for the 21 $1^{\text {st }}$ Century (Cambridge, England: Polity Press, 2002) 269 at 274.

${ }^{182}$ Ernesto Laclau \& Chantal Mouffe, Hegemony and Socialist Strategy: Towards a Radical Democratic Politics (London: Verso, 1985) at 176.

${ }^{183}$ Chantal Mouffe, "Democracy in a Multipolar World" (2009) 37 Millennium Journal of International Studies 549.

${ }^{184}$ William Connolly, The Ethos of Pluralization (Minneapolis: University of Minnesota Press, 1995).

${ }^{185}$ Ibid at 149.

${ }^{186}$ David R. Howarth, "Ethos, Agonism and Populism: William Connolly and the Case for Radical Democracy" 10 British Journal of Politics \& International Relations (2008) 171 at 189.
} 
Bank, and WTO. ${ }^{187}$ He has also suggested an approach to global democracy that leaves the final destination open, rejecting 'blueprints', and advocating a pluralist security community. ${ }^{188}$

In sum, radical democratic pluralism emphasises the values of pluralism, difference, and resistance in global governance and democracy. It promotes global civil society as the primary effective means for achieving a global democracy, suggesting that it ushers a new and promising form of politics and democracy unwedded to the state. With this in mind I now turn to consider the differences and similarities of radical democratic pluralism and GAL.

\subsubsection{Differences}

From this brief survey, several fundamental differences between radical democratic pluralism and GAL emerge. I examine three of them - aims, approach, and abstract nature - and suggest that this reveals the inability for GAL to engage with radical democratic pluralism and the limits of the GAL.

It is a self-evidence but important point: the aims of radical democratic pluralism are considerably more revolutionary than those of GAL. The theorists of the radical democratic pluralist project seek not only to re-conceptualisation democracy in a trans- or supra-national mode, but to establish a new kind of politics. Unlike GAL scholars, they do not seek simply to reform established decision-making processes to enhance accountability, but their fundamental aim is to challenge and re-orient the understanding and meaning of politics as practiced in global governance.

Furthermore, not only is democracy exculpated in the GAL account, but discussions over the fundamental meaning and understanding of democracy are avoided. As Kingsbury, Krisch, and Stewart aver, a radical critique of GAL would illustrate the intractable fissure between reformers and revolutionaries. ${ }^{189}$ While radical democratic pluralism is not motivated by such a critique, its contumacious aims suggest an underlying inconsistency with the limited agenda of GAL.

\footnotetext{
${ }^{187}$ Heikki Patomäki \& Teivo Teivainen, A Possible World: Democratic Transformation of Global Institutions (London: Zed Books, 2004) at 104-107 and 183-188.

${ }^{188}$ Heikki Patomäki, "Problems of democratising global governance: Time, space and the emancipatory process" 9 European Journal of International Relations (2003) 347.

${ }^{189}$ Kingsbury, Krisch \& Stewart, supra note 25 at 52.
} 
Radical democratic pluralism offers a democratic approach in a revolutionary vein. The establishment of global democracy is pursued by means of resistance, a 'new politics' that rejects a small-step, reform minded approach that would simply enhance the existing global institutional arrangement. McGrew, a political scientist, suggests that in the final analysis radical democratic pluralism seeks "to chip away and ultimately destroy sovereignty at all levels of social life". 190 GAL on the other hand seeks to reform and buttress the accountability and therefore legitimacy of the existing systems of global governance. Its approach to change is overwhelmingly smallstep and reform minded at odds with the 'new politics' of radical democratic pluralism.

However, it is easy to oversimplify the antithetical nature of the respective approaches. As mentioned, Kingsbury, Krisch, and Stewart discuss the issue of reform versus revolution and contemplate whether GAL may serve to legitimate and stabilise the global order when radical change is required. ${ }^{191}$ While not coming to a definitive conclusion, they suggest that GAL may work to empower people from the South and bring promise to the most disadvantaged groups. ${ }^{192}$ We also see that radical democratic pluralism faces criticism from anarchists who offer a different interpretation of its aims and approach. Daniel Murray, an anarchist theorist, claims that the radical democratic pluralist approach " $\operatorname{seek}[\mathrm{s}]$ to improve what is seen as an imperfect system rather than radically transform it". 193

The last point of divergence I explore is the intellectual and theoretical structures of GAL and radical democratic pluralism. The latter theory is a largely abstract, heterogeneous endeavour that draws upon analysis from a variety of sources including philosophy, sociology, feminism, and psychology. In this it draws from a broad range of intellectual traditions. ${ }^{194}$ Radical democratic pluralist scholars have been drawn to the empirical issues within globalisation and global governance, such as the rise of new social movements, however radical democratic pluralism theory has largely developed by intellectual critique.

\footnotetext{
${ }^{190}$ Anthony McGrew, "Democracy Beyond Borders?" in David Held \& Anthony McGrew, eds., The Global Transformations Reader: An Introduction to the Globalization Debate (London: Polity Press, 2000) at 412.

${ }^{191}$ Kingsbury, Krisch \& Stewart, supra note 25 at 52.

192 Ibid.

${ }^{193}$ Murray, supra note 180 at 4.

${ }^{194}$ One commentator has suggested these sources are too broad, criticising Mouffe's desire "to bring all the major contemporary theoretical and political movements under her theoretical umbrella" (Susan Hekman, "Radical Plural Democracy: A New Theory for the Left?" (1996) Negations)
} 
In contradistinction, GAL is largely pragmatic endeavour that has drawn upon existing practices or examined case-studies in order to drive its development. As such, there has been little explicit and developed discussion of the theoretical apparatuses supporting its claims, such as administrative law, accountability, and rule of law. In contrast to the broader intellectual sources of radical democratic pluralism, GAL has largely located its intellectual resources in law and legal theory. For example, Harlow's examination of sources for the principles of GAL examined mostly domestic and international law.

\subsubsection{Similarities}

Despite a number of salient differences, I suggest GAL and radical democratic pluralism share certain features. Here I explore their common emphasis on participation and the engagement of civil society.

Radical democratic pluralism proposes the enhancement participation by all people, particularly those currently marginalised, in global governance decision-. Broader participation of individuals in particular in decision-making is a fundamental feature of its theory. ${ }^{195}$ As I explored in deliberative democracy, GAL seeks to promote mechanisms for participation as an important mechanism for increasing accountability. However, as was explored in my analysis on GAL and deliberative democracy, GAL's conceptualisation of participation differs to that offer by radical democratic pluralism. In particular, the notion of direct, as opposed to indirect or representative participation, has particular affinity in radical democratic pluralism. ${ }^{196}$ Thus, radical democratic pluralism exhibits are far stronger version of participation than GAL.

The other key commonality between radical democratic pluralism and GAL is a commitment to the promotion of global civil society and the enhancement of its role in global governance. Radical democratic pluralism suggests global civil society represents the primary, if not exclusive, site for democratic resistance. Enhancing the opportunities for NGOs and alike to participate in global governance features highly in its scholarship. Patomäki for one has proposed several enhancements to the World Social Forum. GAL scholars have explored numerous mechanisms for enhancing the role of civil society in global governance as Kingsbury,

\footnotetext{
195 Joshua Cohen \& Archon Fung, "Radical democracy" 10 Swiss Journal of Political Science (2004) 23 at 23.

${ }^{196}$ Ibid at $23 \& 25$.
} 
Krisch, and Stewart explained that, "global administrative law might take pragmatic steps towards a stronger inclusion of affected social and economic interests through mechanisms of participation and review open to NGOs and other civil society actors...". 197

However, while both GAL and radical democratic pluralism envisage a global order structured with key involvement by NGOs and similar, I suggest GAL scholarship retains the priority of states and limits participation by global civil society actors so that it consistent with this position. Thus, while the role of civil society may be endorsed by both approaches, radical democratic pluralism offers a fuller and more privileged position of it vis-à-vis state actors.

\subsubsection{Engagement with radical democratic pluralism}

An analysis of key features of both GAL and radical democratic pluralism reveals fundamental dissonance between the two theories. For GAL to adopt a radical democratic pluralist approach it would require substantial reformulation of key tenets.

Unlike in its relationship to deliberative democracy and cosmopolitan democracy, GAL does not to any noticeable extent already reflect or promote a radical democratic pluralist vision of global governance. The self-limiting ambition of GAL is patently inconsistent with radical democratic pluralism because the latter seeks to undermine the existing structures of politics while GAL fundamentally seeks to enhance them in ways that promote accountability.

While it is arguable how 'revolutionary' radical democratic pluralism is towards global governance, the piece-meal, pragmatic approach of GAL towards reform undermines the radical democratic template. Whereas Krisch suggests GAL and Global constitutionalism pursue different but consistent paths, I suggest the aims of GAL and radical democratic pluralism are ineluctably in tension. The deeply theoretical nature of much of radical democratic pluralism's discussion over 'real' democracy and the diverging approaches it seeks to cohere provides further barriers for GAL to adopt the radical project. An examination of how the alternative projects would view the case study of the Codex Commission and the New Zealand Food Bill.

\footnotetext{
${ }^{197}$ Kingsbury, Krisch \& Stewart, supra note 25 at 102.
} 
Radical democratic pluralism would provide an array of critiques regarding the standard-setting activities of the Codex Commission as well as the legitimacy of the entire organisation. The Codex Commission is in its present form a paradigmatic form of the 'top-down' approach to global governance that the radical democratic vision eschews. The standards are set by a number of elites with implementation dictated upon New Zealand (and other states) and its communities by legal and market pressures with little ability to challenge this.

Radical democratic pluralism would also critique the forms of participation available to individual New Zealanders in decision-making over the food-safety standards - lobbying New Zealand government representatives and promoting NGO participation in 'notice and comment' procedures - as deeply inadequate because they are indirect, unequal, and reliant on existing state structures. For example, Mouffe's analysis of the Codex Commission and the Food Bill may highlight the lack of possibility for New Zealanders in choosing between real alternatives (such as rejecting the Codex Commission standards) and would be deeply sceptical of the Codex Commission's food-safety standards affirmed by a 'consensus' of member representatives.

On a deeper level, the Codex Commission is heavily embedded in existing (state) sovereignty as a body established by two inter-government organisations (the FAO and WHO) and linked to the WTO system. In short, the Codex Commission is an almost exemplary form of geo-governance from above that the radical democratic pluralist tradition refutes and seeks to transcend. As such, it would reject the legitimacy of the Codex Commission and prescribe the need for alternative sites of politics that would empower New Zealand individuals and communities (amongst others) to regulate their own food safety. This may be in the form of localised foodsafety self-governance through informal codes generated by ad-hoc working-bodies that allow for a wide-range of viewpoints and participants. Or it may suggest a series of permanent, elected peoples' assemblies from local to regional that discuss food-safety outside the state remit. In any case, issues regarding the substantive output and foundational norms of such bodies would be challengeable.

In deep contrast, GAL offers tools for the enhancement of participation, review, and transparency within the Codex Commission through reforming existing structures. Its vision does not wholly reject the standard-setting activities of the Codex Commission and their implementation in New Zealand nor seek to displace the privileged position of state actors. 
Enhanced participation of individuals and non-state actors in its decision-making procedures would be welcomed, but on the basis of existing structures of politics and without aiming to challenge the edifice of global governance.

I suggest that what the inability of GAL to engage with radical democratic pluralism exposes is a latent conservatism and realism in the GAL tradition. The reforms proposed by GAL leave the underlying structures of power and ideological bias in place. GAL views global (at least electoral) democracy as 'intractable' and seeks to work within the established institutional and social environment. Its defence of this position is pragmatism; however, viewed through the prism of radical democratic pluralism it appears as a failure to address the real and deep symptomatic problems with democracy in the world.

\section{Conclusion}

The New Zealand Food Bill illustrates the large democratic and legitimisation lacuna that pervades global governance. New Zealanders, jealous of their food-producing prerogative and with a strong and critical tradition of democracy, reacted strongly to the perceived encroachment on these rights and freedoms by the Codex Commission. These concerns cannot simply be dismissed as "anti-globalisation" hyperbole by isolationists; the detractors were large and varied and New Zealand as a whole has a proud history of international cooperation.

What the New Zealand Food Bill shows is that issues of democracy and legitimacy in global governance are of considerable and practical importance as global governance regimes, like the Codex Commission, multiply and their scope of power and influence increases. Even small, distant countries now find themselves under legal and political pressure to adopt certain norms and their nationals are subject to the legal determination of their situation by global governance bodies.

GAL is a positive step forward in the conceptual and normative framework response to this; it has helped to expose areas of governance previously overlooked, offered tools to militate against some of the worst excesses of global governance, and helped to enhance the accountability of new global actors wielding public power. However, seven years after GAL was introduced into the legal lexicon an examination of the New Zealanders Food Bill illustrates and affirms the fundamental limitations and misapprehensions of its approach. The substantive merit of global 
norms and laws are excluded as is the entire question of democracy. This is not simply a negligible or acceptable side-effect of framing; major issues over the fairness, impact, burden, motivation, creation, and context of the New Zealand Food Bill are missed. Neither can the narrow GAL approach be defended where it misapprehends the nature of global governance, elides democracy with one fixed concept, and posits preternatural knowledge of reform possibilities.

Instead, I have shown that GAL must engage with democratic theorising if it is still to retain relevance and a realistic possibility of addressing the major democratic and legitimacy deficits of international law and global governance in the $21^{\text {st }}$ century. I have explored the possibility of GAL to acknowledge and adopt three theories of global democracy - deliberative, cosmopolitan, and radical democratic - and concluded deliberative democracy may provide the most accessible path forward. However, while deliberative democracy may offer the least difficult democratic theory that GAL can assimilate or promote, it may not be the best or most democratic theory. When addressing the democratic question GAL scholars face an on-going question faced by many theorists and political communities: what type of democracy is the "best" and which should we adopt?

It is likely that GAL scholars will be reluctant to engage in such broader theorising, concerned over the need to do so, the complexity in doing so, and the potential distension of GAL as a result. However, the need is pressing, the conceptual resources are available, and the result are achievable. I also point out that my approach to democratic engagement is a brief exploration in this area; it does not seek to formulate a definitive technique. Perhaps on final analysis GAL cannot integrate or promote any democratic theory without losing its coherence and effectiveness. In such a case it should be ejected; the issues at stake are too important to let doctrine lead us nor will they dissipate - in New Zealand a new Natural Health Products Bill is being introduced that one critic has compared to the "other leg" of the Codex Commission's agenda in New Zealand that will "will kick New Zealanders in the guts". 198

\footnotetext{
198 "Use the Natural Health Products Bill to counter the Food Bill" (6 February 2012), online: NZ Food Security <http://nzfoodsecurity.org/2012/02/06/use-the-the-natural-health-products-bill-to-counter-the-food-bill/>.
} 
In this pursuit, what may be helpful to legal scholars of global governance - whether GAL or otherwise - is to always keep in mind one critical question: what does this theory do to connect, in a real, democratic, and effective way, the coffee grower in Kenya to the fair-trade certification of its coffee, the tourist operator in Brazil seeking a loan from a state bank to the Basel Committee, a refugee in Syria to the UNHCR, and an apricot grower in New Zealand to the Codex Commission, 